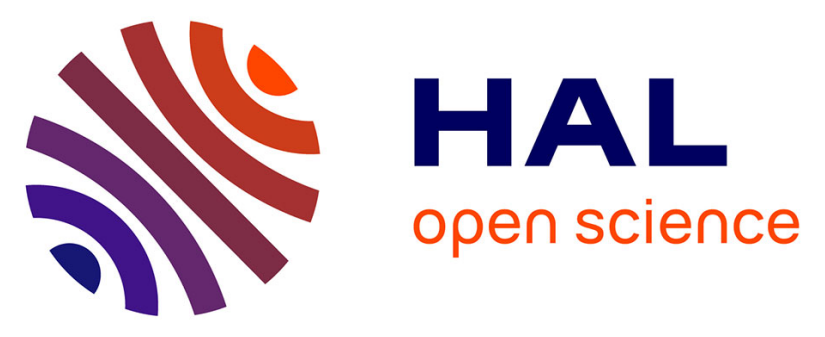

\title{
Technological evolution of ceramic glazes in the renaissance: In situ analysis of tiles in the Alcazar (Seville, Spain)
}

Laurence de Viguerie, Maria Robador, Jacques Castaing, Jose L Perez-Rodriguez, Philippe Walter, Anne Bouquillon

\section{To cite this version:}

Laurence de Viguerie, Maria Robador, Jacques Castaing, Jose L Perez-Rodriguez, Philippe Walter, et al.. Technological evolution of ceramic glazes in the renaissance: In situ analysis of tiles in the Alcazar (Seville, Spain). Journal of the American Ceramic Society, 2019, 102 (3), pp.1402-1413. 10.1111/jace.15955 . hal-02179294

\section{HAL Id: hal-02179294 \\ https://hal.sorbonne-universite.fr/hal-02179294}

Submitted on 10 Jul 2019

HAL is a multi-disciplinary open access archive for the deposit and dissemination of scientific research documents, whether they are published or not. The documents may come from teaching and research institutions in France or abroad, or from public or private research centers.
L'archive ouverte pluridisciplinaire HAL, est destinée au dépôt et à la diffusion de documents scientifiques de niveau recherche, publiés ou non, émanant des établissements d'enseignement et de recherche français ou étrangers, des laboratoires publics ou privés. 
TECHNOLOGICAL EVOLUTION OF CERAMIC GLAZES IN THE RENAISSANCE: INSITU ANALYSIS OF TILES IN THE ALCAZAR (SEVILLE, SPAIN)

L de Viguerie $^{1}$, M. D. Robador ${ }^{2}$ J Castaing $^{1}$, J.L. Perez-Rodriguez ${ }^{3}$, P Walter ${ }^{1}$, A Bouquillon $^{4,5}$

${ }^{1}$ Sorbonne Université, LAMS, UMR 8220 CNRS-UPMC Paris 06, Place Jussieu, F-75005 Paris

${ }^{2}$ Technical Architecture Faculty (University of Seville), Reina Mercedes 4, E-41002 Seville

${ }^{3}$ Materials Science Institute of Seville (CSIC-University), Americo Vespucio 49, E-41092 Seville

${ }^{4}$ Centre de Recherche et de Restauration des Musées de France (C2RMF), Palais du Louvre, F-75001 Paris, France

${ }^{5}$ Chimie ParisTech, PSL Research University, CNRS, Institut de Recherche de Chimie de Paris (IRCP), F-75005 Paris, France.

\section{ABSTRACT}

The Alcazar Palace (Seville, Spain) is famous for its ceramic decorations; $16^{\text {th }}$ century wall tiles of different typologies have been analyzed in order to relate the manufacturing process of their colored glazes to the evolving technologies of the Renaissance. Chemical and mineralogical compositions have been determined in situ by non-destructive X-ray fluorescence (XRF) and X-ray diffraction (XRD) on arista ceramics in the Cenador de Carlos Quinto, and majolica ceramics in the Palacio Gotico and the Royal oratory. The arista style belongs to the local Hispano-Moresque ceramic tradition. Majolica tiles have the complex microstructures of glazes from Italy. The two types are clearly differentiated by their typology, morphology (curved vs flat surface), and also microstructure (single vs multilayers), glaze chemistry, and use of different coloring agents. Moreover, we found different glaze chemistries in the investigated majolicas, which correspond to different artists and/or practices.

\section{Introduction}

During the Renaissance, ceramics in Western Europe evolved with the development of decorative colored glazes. Eastern influences had reached the Iberian Peninsula during the Arabic period and induced technological and cultural changes. The chemistries of 11th to 15th 
century ceramics from the Alcazar Palace ${ }^{1}$ have recently been explored using shards found during archaeological excavations. In the $16^{\text {th }}$ century, after 1492 , the year that Granada was defeated by the Catholic Monarchs and that Columbus made his journey, Seville became one of the largest cities of the Renaissance because of the trade monopoly with America. Tiles with colored glazes displaying geometric designs inspired by the arabesque were produced in large quantities. They were made using the arista (ridge tiles) and the cuerda seca (dry cord) techniques. ${ }^{2,3}$ Both have borderlines to avoid the mixing of different glaze colors during firing. In the arista technique, the green body is stamped to raise ridges separating the zones to be glazed. These techniques produce tiles with transparent glazes that are not flat. Conversely, the innovation that appeared in Italy with majolica style makes it possible to "paint" directly on ceramics covered with white opaque glazes. In 1557, Piccolpasso published his treatise on the potter's art that describes the preparation techniques for colored glazes ${ }^{4,5}$ all the aspects of majolica fabrication have been discussed by Tite, who confirms Piccolpasso's description thanks to microstructural and chemical observations. ${ }^{6}$ Very briefly, water suspensions with the ingredients for white glazes ( $\mathrm{Pb}-\mathrm{Sn}$ silicates) were applied to ceramic bodies (fired around $1000^{\circ} \mathrm{C}$ ). The decorations were then hand-painted by the artists and then fired around $900^{\circ} \mathrm{C}$. Sometimes, a thin transparent $\mathrm{Pb}$ glaze (coperta) was deposited to achieve a glossy surface. Glazes may therefore include up to three layers . ${ }^{6,7}$

The art of majolica ceramics was developed during the years 1480-1530, reaching maturity in the second half of the $16^{\text {th }}$ century with a large production of decorated objects (dishes, ewers, etc.) and tiles. ${ }^{8}$ The $16^{\text {th }}$ century in Seville corresponds to an exceptional moment in the evolution of ceramics with the birth of the majolica style around 1500 , followed by a gap in this production after 1528 until 1578. The Alcazar Palace offers a great opportunity to follow this evolution thanks to the transformations of the building made at this time by the Catholic Monarchs. They commissioned Niculoso Pisano to make two majolica tile Altarpieces in the Palace: ${ }^{9,10}$ one, made in 1504 and described in detail by Pleguezuelo, ${ }^{11}$ still exists in the oratory of the Royal apartments (fig. 1) whereas the other one is nowadays missing. Niculoso Pisano is known as the artist who brought the majolica skill in Seville. Pisano's first documented work in Seville is a tomb in the church of Santa Ana (1503) and his last works date to $1526 .{ }^{9-12}$ The disappearance of the art of majolica ceramics in Seville, after Pisano's death, is attested in the 1561 contract between Frans Andries from Antwerp and Roque Hernandez from Triana. The role of Andries was to teach Roque the art of painting on 
ceramics. $^{13,14}$. This corresponded to the re-birth of majolica in Seville, the most important artist being Cristobal de Augusta who married Roque's daughter in 1569. He signed various majolica tile-works in Seville, including the continuous tile high dado in the Palacio Gotico $(1578)^{10}$ that looks as if the Palace were decorated with yellow tapestries (fig. 2a), featuring animals, cherubs, etc..., mostly celebrating the Emperor Carlos Quinto, (1519-1556) (fig. 2b). Initially, the Palacio Gotico included four rooms. At the time of the Lisbon earthquake (1755), one of the rooms was damaged and, then, destroyed. Tiles were used in reconstructions of the Palace, in particular in the Jardin de las Flores. The remaining rooms of the Palacio Gotico include the Sala Cantarera and the Salon de Baile, which is now a highlight of the Alcazar tourist visit (fig. 2).

An example of arista tiles, produced during the gap in majolica production, can be found in the Cenador de Carlos Quinto which is a square pavilion in the Alcazar gardens (fig. 3): the internal and external walls are covered with arista tiles featuring colored floral elements (fig. 3). This pavilion is a former Arabic building transformed between 1543 and $1546 .{ }^{10,16}$ The architecture and the conservation state of the pavilion have been recently studied in detail. ${ }^{15} \mathrm{~A}$ similar architectural treatment was applied to the Casa de Pilatos, an aristocratic Palace built in Seville also in the middle of the $16^{\text {th }}$ century. ${ }^{2,3}$

The objective of this investigation is to bring to light the changes in ceramic technology that took place in the Renaissance by means of analyses of $16^{\text {th }}$ century majolica and arista tiles in the Alcazar Palace. Beyond visual aspects, chemical and mineralogical compositions as well as microstructures are necessary to characterize the production technology of the tiles. As is required for precious works of art, non-invasive portable means of analysis were chosen: portable X-ray fluorescence $(\mathrm{XRF}){ }^{17}$ providing the elemental concentrations of the colored glazes and X-ray diffraction (XRD) to determine the crystalline phases. ${ }^{18,19}$ Portable XRF developed in the past 20 years to perform in situ analyses of valuable art works, has been already applied to ceramics but mostly used for qualitative or semi-quantitative analysis. ${ }^{20,21}$ XRF has been complemented with the study of a few micro-samples taken from tiles that provide in-depth information of the microstructure.

There are two challenges in the work; first, the variety of hues in the painted majolica glazes, associated with spatial variations of the glaze compositions, and, second, the huge area of the tile surfaces (about $400 \mathrm{~m}^{2}$ in the Palacio Gotico and $180 \mathrm{~m}^{2}$ in the Cenador de Carlos 
Quinto).

\section{Experimental conditions}

\section{(1) Object description}

This article concerns the characterization of three $16^{\text {th }}$ century ceramic works of art in the Alcazar: (1) the Pisano majolica tile Altarpiece in the oratory of the Royal apartments (fig. 1); (2) two rooms of the Palacio Gotico i.e. the Salon de Baile and the Sala Cantarera, hereafter referred to as the large room (37m x $7 \mathrm{~m})$ and the small room (17m x 7m); (3) the Cenador de Carlos Quinto. The analytical measurements (XRF, XRD) were restricted to zones between 1 $\mathrm{m}$ and $2 \mathrm{~m}$ from the floor of these three rooms. A few samples were taken from the tiles, including ones in the Jardin de las Flores.

\section{(2) In situ analytical methods}

\section{Experimental set-up}

In-situ XRF and XRD measurements have been performed using two portable in-house developed systems already used in the Alcazar for wall paintings ${ }^{22}$ One system was designed to perform simultaneously XRD and XRF; it is equipped with an air-cooled iMOXS source (IFG-GmbH, Berlin) operated at $28 \mathrm{~W}$ power and $40 \mathrm{kV}$ high voltage, with a copper anode and a poly-capillary semi-lens that provides a parallel beam. ${ }^{18,19,23} \mathrm{XRD}(\mathrm{Cu}-\mathrm{K} \alpha, \lambda=0.154$ $\mathrm{nm}$ ) has geometrical constraints, in particular an incident beam at $10^{\circ}$ from the object surface. With adequate slits, the surface irradiated by X-rays is about $3 \times 4 \mathrm{~mm}^{2}$. A 2-D detection of $\mathrm{XRD}$ is provided by an imaging plate perpendicular to the incident beam. XRF is measured with a silicon drift detector (SDD; resolution $150 \mathrm{eV} \mathrm{FWHM}$ at $5.9 \mathrm{keV}$ ) perpendicular to the object.

The other portable XRF is the latest version of an instrument developed and used over the past 10-20 years. ${ }^{17,23}$. The X-ray source is a Moxtek (Orem, USA) Pd-anode tube developing $3 \mathrm{~W}$ power at $30 \mathrm{kV}$ high voltage. The $\mathrm{Pd}-\mathrm{XRF}$ beam (diameter about $1 \mathrm{~mm}$ ) strikes the surface of the object at $45^{\circ}$ and the SDD (resolution $136 \mathrm{eV} \mathrm{FWHM}$ at $5.9 \mathrm{keV}$ ) is perpendicular to the surface.

Because the Pd-XRF instrument is small, ${ }^{17}$ it is easier to operate than the XRF-XRD; ${ }^{18,19}$ therefore, only the Pd-XRF was used in the Royal oratory (fig. 1). XRD was performed in the 
Palacio Gotico (fig. 2); results are in Supplementary Information. Both XRFs have been used in the Cenador de Carlos Quinto (fig. 3); however as Pd-XRF has been used for only 6 points, those results are only indicated for comparison in Supplementary Information (Table S7).

\section{Data treatment}

Quantitative data treatment was performed on the XRF measurements (from both pieces of equipment): the chemical compositions of the glazes have been calculated from spectra using the PyMca software with the fundamental parameters method. ${ }^{17,23,24} \mathrm{~A} 16^{\text {th }}$ century piece of ceramics (DR1) has been used to adjust the experimental parameters for the calculation of elemental concentrations from both Pd-XRF and XRF-XRD spectra. ${ }^{17}$ The DR1 structure and composition (blue $\mathrm{Pb}$ silicate glaze) being close to that of the ceramics in the Alcazar, corrections have been applied for a few elements (see supplementary information). The concentrations calculated with this method are not normalized to $100 \mathrm{wt} \%$ as they refer to DR1 concentrations and, then, do not depend on the accuracy of the values for light elements. The two XRF systems gave similar concentrations. The relative errors were smaller than 10 wt $\%$ on the BGIRA3 standard glass. ${ }^{23}$ However, the Pd-XRF gives better data than the XRFXRD due to several reasons: (1) the $10^{\circ}$ incidence angle means that the X-ray penetration is 6 times smaller for the XRF-XRD than for the Pd-XRF; (2) quantitative $\mathrm{Cu}$ analysis is not accurate with the XRF-XRD because of the $\mathrm{Cu}$ source peak (fig. S1); (3) the XRF-XRD has about $2 \mathrm{~cm}$ air between the SDD and the object; the XRF lines were too weak to obtain data for light elements above $\mathrm{Si}$ in the periodic table (fig. S1).

PyMca takes into account the differences of X-ray absorption depending on the considered energy: the values of the attenuation length for $\mathrm{Pb}$-rich matter are about $1 \mu \mathrm{m}$ at $1.7 \mathrm{keV}$ (Si$\mathrm{K}), 20 \mu \mathrm{m}$ at $8 \mathrm{keV}$ and $130 \mu \mathrm{m}$ at $25 \mathrm{keV}$. This cannot be neglected for multilayered glazes and for an object covered with a weathering/contamination layer, such as might be expected on 500 year old tiles. For high energy lines ( $\mathrm{Pb}-\mathrm{L}, \mathrm{Sn}-\mathrm{K}, \mathrm{Sb}-\mathrm{K} \ldots)$, surface layers can be neglected. In our results, the concentrations deduced from $\sim 2-3 \mathrm{keV}$ XRF lines (Pb-M, Sn-L, Sb-L, etc.) may be different from the ones deduced from the high energy lines. The comparison of concentration values for $\mathrm{Pb}-\mathrm{L}$ and $\mathrm{Pb}-\mathrm{M}, \mathrm{Sn}-\mathrm{K}$ and $\mathrm{Sn}-\mathrm{L}$, etc. then indicates the presence of several layers. 


\section{(3) Sample analysis}

To check for the homogeneity of the glazes, it is useful to complement the data from XRF non-destructive investigations with in-depth observations. For that purpose, a few microsamples were taken from the Cenador de Carlos Quinto, the Palacio Gotico and the Jardin de las Flores. Cross-sections of the glazes were prepared. Optical microscopy (OM) and SEMEDX analyses were carried out with the laboratory equipment used in previous investigations. ${ }^{1,22}$ No quantitative analysis has been carried out by SEM-EDX.

\section{Results}

\section{(1) Altarpiece by Pisano}

Average element concentrations in different glaze colors of the Altarpiece tiles (fig. 1) are reported in table 1 (detailed results in supplementary information). Standard deviations are given when there are more than seven measurements. They may correspond to a distribution of coloring ion concentrations that induce hue variations. The dominant colors are blue for drawings and brown/orange to yellow for the background.

It is to be noted that the average concentrations for $\mathrm{Pb}-\mathrm{L}$ are very close to those for $\mathrm{Pb}-\mathrm{M}$, suggesting that the $\mathrm{Pb}$ silicate matrix is homogeneous throughout the glaze. Conversely, a different conclusion can be drawn for $\mathrm{SnO}_{2}$ that is at concentrations about 5 times lower near the surface $(\mathrm{Sn}-\mathrm{L})$ than at some depth in the glaze $(\mathrm{Sn}-\mathrm{K})$. A similar conclusion holds for $\mathrm{Sb}$ in yellow glazes. It is worth mentioning that these conclusions rely on the quality of the PyMca de-convolution for three lines (Ca-K, Sn-L and Sb-L) which has been checked for 7 $\mathrm{wt} \% \mathrm{CaO}$ and $13 \mathrm{wt} \% \mathrm{SnO}_{2}$ in a soda-lime glass. ${ }^{23}$ Therefore, the glazes seem to include several layers of about the same $\mathrm{Pb}$ contents, the top layer containing less $\mathrm{Sn}$ and $\mathrm{Sb}$ than the in-depth layers.

The opaque $\mathrm{Pb}$ silicate layer appears white due to cassiterite $\left(\mathrm{SnO}_{2}\right)$ micro-crystals, a wellestablished technique since the first millennium ${ }^{25}$ : similar $\mathrm{SnO}_{2}$ contents (about $6 \mathrm{wt} \%$ ) have been observed in all the colors (Table 1). The white color is modulated by variable blue or grey hues to give depth and expression to the scenes. The painter's gesture is clear in the faces of the figures; $\mathrm{Fe}, \mathrm{Co}$ and $\mathrm{Ni}$ concentration variations allow the artist to create shadows and effects giving perspective. This was the case for the face of Saint Elisabeth (old woman to the right of the Virgin in the Visitation, fig. 1) where we measured three neighboring points from 
a clear zone to a dark zone; concentrations increased from 0.7 to $1.4 \mathrm{wt} \% \mathrm{Fe}_{2} \mathrm{O}_{3}$, from zero to $0.45 \mathrm{wt} \% \mathrm{CoO}$ and from zero to $0.24 \mathrm{wt} \% \mathrm{NiO}$, reminiscent of the art of canvas painters. ${ }^{26}$

For yellow/brown glazes, we performed 13 measurements: results are summarized in table 1. They suggest a coloration due to Naples yellow $\left(\mathrm{Pb}_{2} \mathrm{Sb}_{2} \mathrm{O}_{7}\right)$ that usually gives a "lemon" yellow $^{23,27}$ unlike the orange/brown color ubiquitous on the Altarpiece (fig. 1). Yellow hues can be modified by changing the $\mathrm{Pb}$-antimonate stoichiometry or by partial substitution of $\mathrm{Sb}$ with cations such as $\mathrm{Si}, \mathrm{Fe}, \mathrm{Zn}$, etc. ${ }^{4,5,7,28}$. Zn was present in four XRF spectra taken in the blonde hair of the Virgin and of the $2^{\text {nd }}$ woman to the right (Visitation; fig. 1). This specific recipe used for the hair of the central characters underline the artist's work which makes use of several different yellow hues.

Turquoise corresponds to variations in green. The matrix compositions are similar to those of other colors (Table 1) with $\mathrm{CuO}$ concentrations between $0.6 \mathrm{wt} \%$ and $4 \mathrm{wt} \%$. A significant amount of $\mathrm{Zn}$ was found for a turquoise jewel in the hair of the Virgin in the Visitation $(0.14$ wt $\% \mathrm{ZnO}$ and $0.86 \mathrm{wt} \% \mathrm{CuO}$ for point 80 ; supplementary information). Zinc content is seldom given in ancient ceramic analyses; ${ }^{11,29,30,31}$ a concentration of $0.02-0.1 \mathrm{wt} \% \mathrm{ZnO}$ corresponds to an impurity level, and it is often higher for green glazes. This could be due to $\mathrm{Cu}$ raw materials (brass) or to the presence, underneath the green, of a Zn-rich yellow glaze. There is no chemical indication that the green was obtained by mixing Co-blue and $\mathrm{Pb}$ antimonate yellow (Table 1).

Blue is present as lines corresponding to the painter's creation, and also as a blue glaze (fig. 1). In the first case, it corresponds to thin layers of color deposited with a brush on top of the white glaze, in contrast to $100-200 \mu \mathrm{m}$ thick blue glazes. The variable intensity of the blue may be due to fluctuations in layer thicknesses or in $\mathrm{CoO}$ concentrations $(0.2-1.7 \mathrm{wt} \%)$, as well as to variable Sn contents. Note that $0.4-1.2 \mathrm{wt} \% \mathrm{CoO}$ and $4-26 \mathrm{wt} \% \mathrm{SnO}_{2}$ are common in Della Robbia blue glazes. ${ }^{17,29}$

Finally, three purple points and one red point were analyzed. The purple is obtained with about $1 \mathrm{wt} \% \mathrm{MnO}$ and the red contains $2.3 \mathrm{wt} \% \mathrm{Fe}_{2} \mathrm{O}_{3}$. Red is a rare color at that time, except in Iznik pottery where it corresponds to Fe-rich under-glaze layers. ${ }^{32}$ 


\section{(2) Majolica tiles by Augusta}

The Palacio Gotico color is dominated by yellow (fig 2) with majolica wall tiles. XRF-XRD measurements have been performed on 19 points (Table 2). Crystalline phases have been determined from XRD diagrams collected simultaneously with XRF for 12 points (Supplementary Information). Both techniques reveal differences between the glazes in the large room and the small room. A dozen cross-sections have been examined. Optical microscopy (OM) shows that glazes frequently include two layers as observed for Renaissance majolica wares. ${ }^{5,8}$

White glaze is relatively rare in the Palacio Gotico. We have performed only one measurement on the cheek of Carlos Quinto (fig. 2b). The composition is consistent with most observations for coeval ceramics, but $\mathrm{Sn}-\mathrm{L}$ and $\mathrm{Pb}-\mathrm{M}$ values suggest higher concentrations at the surface. The white glaze could be an over-glaze "painting" on a grayish zone. An alternative is that the grayish color is due to alteration which may, indeed, induce the formation of $\mathrm{Pb}$-enriched surfaces. ${ }^{1} \mathrm{No} \mathrm{Sb}$ is expected in a white glaze; the small concentration (Table 2) may be due to the proximity of yellow glaze, or to inaccurate calculations. A cross-section from the small room shows an 80-100 $\mu \mathrm{m}$ thick opaque glaze with bubbles (diameter $<30 \mu \mathrm{m}$ ), small $\mathrm{SnO}_{2}$ (cassiterite) particles and large particles (mainly quartz, and probably feldspars). The SEM-EDX spectrum is dominated by Si with $\mathrm{Pb}, \mathrm{Sn}$ and other elements as expected for white color.

XRF for yellow glazes has been measured five times in the large room and twice in the small room. The results show differences between the chemistries in the small and the large rooms. The amounts of $\mathrm{Sb}$ are about the same for yellow and orange in both rooms (6-7 wt\%) but the small room has $7 \mathrm{wt} \% \mathrm{SnO}_{2}$, three times the value of that found in the large room (Table 2). Only the yellow glaze in the large room contains a high level of $\mathrm{Zn}$ (average $6 \mathrm{wt} \%$; data from $4 \mathrm{wt} \%$ to $9 \mathrm{wt} \%)$.

Here again, it is interesting to compare $\mathrm{Sn}-\mathrm{K}, \mathrm{Sb}-\mathrm{K}$ and $\mathrm{Pb}-\mathrm{L}$ lines, typically coming from 100-150 $\mu \mathrm{m}$ thick layers, to the low energy ones, i.e. Sn-L, Sb-L and $\mathrm{Pb}-\mathrm{M}$ lines, which come from the surface (a layer 5-10 $\mu \mathrm{m}$ thick). For all the yellow as well as the orange glazes in the small room, there is a gradient of two of the three elements ( $\mathrm{Sn}, \mathrm{Pb}, \mathrm{Sb}$; Table 2) suggesting the presence of two layer glazes. 
Two yellow samples have been taken in each room. Cross-section OM shows that, for the large room (Fig. 2a), there is a thin yellow layer (about $10 \mu \mathrm{m}$ ) on top of a $110-180 \mu \mathrm{m}$ white layer (Fig. S5). This is consistent with the $\mathrm{Sb}$ concentration gradient $\left(25 \mathrm{wt} \% \mathrm{Sb}_{2} \mathrm{O}_{5}\right.$ for L-line and $8 \mathrm{wt} \%$ for K-line; Table 2). In the small room, one sample presents the same microstructure and the other sample has two layers of comparable thicknesses (total of 100 $\mu \mathrm{m})$, the latter being compatible with the absence of a significant gradient for $\mathrm{Sb}$ in XRF (Table 2). These differences may be due to irregularity in the glaze processing. SEM-EDX spectra on particles in yellow layers suggest that they are $\mathrm{Pb}$-antimonate with $\mathrm{Sn}, \mathrm{Fe}$ and $\mathrm{Zn}$. $\mathrm{XRD}$ suggests the presence of $\mathrm{Pb}_{2} \mathrm{SnSbO}_{6.5}$ although $\mathrm{Pb}$-antimonate may include other dissolved cations undetected by XRD (Supplementary Information).

Four XRFs have been performed on blue glazes (fig. 2), one in the small room and three in the large room. The blue color is due to the presence of about $1.5 \% \mathrm{CoO}$. In both cases, arsenic and bismuth are present; concentrations have been determined from As-K $\beta$ line (11.7 $\mathrm{keV}$ ) and from $\mathrm{Bi}-\mathrm{L}$ lines $(9-15 \mathrm{keV})$ which are isolated from $\mathrm{Pb}-\mathrm{L}$ lines. The $\mathrm{CaO}$ concentrations are spread from 2 to $23 \mathrm{wt} \%$ in the large room $(4 \mathrm{wt} \% \mathrm{CaO}$ average without the $23 \mathrm{wt} \%$ value, Table 2); the high $\mathrm{CaO}$ content is very likely due to a surface contamination. There is a significant amount of $\mathrm{Sn}\left(3 \mathrm{wt} \% \mathrm{SnO}_{2}\right.$ in the large room and $7 \mathrm{wt} \%$ $\mathrm{SnO}_{2}$ in the small room). Five samples were taken from blue glazes in the two rooms. The glazes appear as thick blue layers, except in the large room (Fig. S6) where there is a thin blue layer $(15-30 \mu \mathrm{m})$ on a white layer $(13-190 \mu \mathrm{m})$. This observation very likely corresponds to variable blue from painting (Fig. 2b and c). SEM-EDX shows that there are particles with As (also seen in XRF) associated to $\mathrm{Pb}$ and $\mathrm{Ca}$. Other particles are rich in $\mathrm{Sn}$ (cassiterite ) or in $\mathrm{Si}$ (quartz, ...). XRD diagrams in thick glazes are dominated by cassiterite, cristobalite and quartz in the small room, in agreement with the SEM-EDX observations, and by $\mathrm{Pb}$-silicate crystals in the large room blues (supplementary information). Such occurrences are probably associated to poor control of the firing conditions.

The green color is due to the presence of $\mathrm{Cu}$ as revealed by $\mathrm{Cu}-\mathrm{K} \beta$ lines in XRF spectra (fig. $\mathrm{S} 1$ ). Green and yellow glazes have in common the presence of $\mathrm{Sb}$ and $\mathrm{Sn}$ (Table 2), green having similar $\mathrm{Sn}$ amounts, but, lower $\mathrm{Sb}$ concentrations (1 and $2 \mathrm{wt} \% \mathrm{Sb}_{2} \mathrm{O}_{5}$ ). $\mathrm{Pb}$-antimonate is frequent in Della Robbia green glazes $;{ }^{27}$ its presence prevents a bluish tint in majolica 
greens ("mixed green") ${ }^{6}$. XRD revealed cassiterite and $\mathrm{Pb}$-antimonate in the small room (supplementary information), cassiterite being hardly visible in the large room as expected for the $3 \mathrm{wt} \% \mathrm{SnO}_{2}$ content. One cross-section of green glaze from the small room displays a uniform green glaze through its $100-120 \mu \mathrm{m}$ thickness.

Finally, one purple glaze was analyzed in each room. The glaze contains $5 \mathrm{wt} \% \mathrm{MnO}$ associated to bixbyite $\left(\mathrm{Mn}_{2} \mathrm{O}_{3}\right)$ in the large room corresponding to dark purple. The high $\mathrm{Sn}$ content with $8 \mathrm{wt} \% \mathrm{MnO}$ produces the clear purple color in the small room where only cassiterite is observed by XRD (supplementary information). Two cross-sections from the small room were examined by OM and SEM; both glazes include a purple layer (30 to $50 \mu \mathrm{m}$ ) on top of a white layer (50 to $150 \mu \mathrm{m})$ with particles rich in $\mathrm{Sn}$ (cassiterite).

\section{(3) Arista tiles}

The inside walls and the outside walls of the Cenador de Carlos Quinto, are covered with arista tiles. XRF measurements have been performed mostly on the inside walls (fig. 3) with a few points on the $50 \mathrm{~cm}$ high band near the floor, and on the floors made of flat tiles (fig. 3a); they have compositions close to those of the wall tiles given in table 3. The arista design (fig. 3) is repetitive, except for the yellow color that can tend towards the honey/brown (fig. 3a). Eight cross-sections have been prepared from samples from the inside walls. They present uniform colors throughout the glazes. Thicknesses are fairly irregular (200-600 $\mu \mathrm{m}$; up to 1 $\mathrm{mm}$ in places) probably because of the specificity of arista (curved surface) ceramics and the variable sampling locations.

Transparent yellow glazes (Fig. 3b) have nothing in common with those of the Palacio Gotico; $\mathrm{Sn}$ and $\mathrm{Sb}$ are not present. The yellow color is due to $\mathrm{Fe}$; the $1.5 \mathrm{wt} \% \mathrm{Fe}_{2} \mathrm{O}_{3}$ value (Table 3) represents concentrations from 1.1 to $2.4 \mathrm{Fe}_{2} \mathrm{O}_{3}$ explaining variations from yellow to honey/brown (fig. 3a). Brown-beige contains 3-4 wt $\% \mathrm{Fe}_{2} \mathrm{O}_{3}$. The color variations may also be due to insufficient control in the firing conditions (temperature and oxidizing conditions). Blue glazes contain 0.2-0.4 wt\% $\mathrm{CoO}$ and 4-5 wt\% $\mathrm{SnO}_{2}$. Small amounts of As and Bi have been found in some places. The two blue glazes observed on cross-sections are irregular with many bubbles (about 40 in $1 \mathrm{~mm}^{2}$; Fig. S7a) compared to other samples, (the green glaze with two bubbles in fig. S7b as an example). Copper was detected in transparent green glazes, concentration values being calculated only for Pd-XRF (CuO average $2.2 \mathrm{wt} \%$, Table S7). 
Purple has been measured with the XRF-XRD. The color is obtained with Mn, clear purple containing also $7 \mathrm{wt} \% \mathrm{SnO}_{2}$ (cassiterite).

\section{Discussion}

\section{(1) Experimental methods}

XRFs ( 100 measurements) have been obtained in situ with two portable systems, complemented by XRD in the Palacio Gotico. Since XRF and XRD are non-invasive techniques, the analysis is restricted to $5-150 \mu \mathrm{m}$ deep layers from the surface. The two XRF systems have been compared on glass standards ${ }^{23}$; they have shown to give satisfactory quantitative results for arista tiles regarding the glazes inhomogeneity (supplementary information). When possible, it was crucial to take samples to check for the in-depth structure of the glazes. Samples were also taken in the Jardin de las Flores (Flower Garden) where tiles from the Palacio Gotico have been re-used after 1755. Although these tiles are weathered, we observed by SEM that their microstructures and compositions are similar to those found in the Palacio Gotico.

Two limitations have to be taken into account for the interpretation of the XRF data:

(i) The extraction of data from superimposed lines limits the accuracy of the values for several key elements: for example, $\mathrm{Sn}, \mathrm{Sb}, \mathrm{K}$ and $\mathrm{Ca}$ that are present in yellow colors, etc. Concentrations below $0.1-0.5 \mathrm{wt} \%$ must then be taken with caution.

(ii) There are specific sources of errors on concentrations due to the possible presence of various layers and heterogeneities. An example is calcium; the Alcazar is rich in stuccos, hence the presence of plaster has been ubiquitous in the Palace throughout centuries, explaining a few high $\mathrm{CaO}$ concentrations. Majolica glazes can include several layers, some of them being as thin as a few $\mu \mathrm{m}$. The results then depend on the X-ray penetrations compared to the layer thicknesses, their fluctuations being the origin of data scatter. Whenever different concentrations are obtained from two XRF lines having low and high energies $(\mathrm{Pb}, \mathrm{Sn}, \mathrm{Sb})$, we can conclude that the analyzed matter includes several layers. Finally, the presence of particles (quartz, Pb-antimonate, etc.) in the analyzed layers induces an error on glaze concentration values.

\section{(2) Ceramic technology}

The Alcazar Palace is more than 1000 years old. It has been renovated a number of times, 
which accounts for the quantities of materials uncovered by archaeologists, such as $11^{\text {th }}$ to $15^{\text {th }}$ century ceramics (tableware, storage containers, etc.). ${ }^{1}$ In the present investigation, $16^{\text {th }}$ century ceramic tiles, produced in Seville and still present on the walls in three parts of the Palace, have been analyzed with the aim of determining their origins. Tiles are related to the Italian majolica style (Altarpiece and Palacio Gotico, 1504 and 1578 respectively) and the arista tiles are rooted in the local tradition (Cenador de Carlos Quinto, 1543-1546). The three sets of tiles have $\mathrm{Pb}$-silicate glazes with distinct decoration as well as chemical composition and microstructure.

\section{(2.1) Arista ceramics}

The arista tiles in the Cenador de Carlos Quinto have transparent colored glazes, as in $15^{\text {th }}$ $16^{\text {th }}$ century Hispano-Moresque tiles, ${ }^{33}$ except when they contain $\mathrm{SnO}_{2}$ as in white, blue and clear purple. The purple is rare in Hispano-Moresque tiles. It has been found once in the Palacio de Sintra (Portugal) in a study including seventy tiles from the Iberian Peninsula. ${ }^{33}$ This suggests a common origin for these ceramics. In a Portuguese Monastery, ${ }^{34}$ white and blue glazes are opacified with 7-14 wt $\% \mathrm{SnO}_{2}$ and have 35-45 wt $\% \mathrm{PbO}$ and 30-38 wt $\% \mathrm{PbO}$, respectively. In the Cenador de Carlos Quinto, the concentrations are below these ranges.

The colors are obtained with the usual ions, $\mathrm{Co}$ in blue $(0.4-0.5 \mathrm{wt} \% \mathrm{CoO}), \mathrm{Cu}$ in green $(2 \%$ $\mathrm{CuO})$ and $\mathrm{Fe}$ in yellow ( $2 \mathrm{wt} \% \mathrm{Fe}_{2} \mathrm{O}_{3}$; up to $4 \mathrm{wt} \%$ in beige/honey/amber). In contrast to majolicas, no $\mathrm{Sb}$ was found in yellow glazes although its use has been known since the second millennium B.C. ${ }^{5,23}$ These characteristics are common to all the arista tiles studied by Coentro et al. ${ }^{33}$ except that they found two green glazes containing $\mathrm{Sn}\left(2.5-8.6 \mathrm{wt} \% \mathrm{SnO}_{2}\right)$ in two arista tiles from Seville belonging to the Instituto Valencia de Don Juan collection. All the arista tiles cannot come from a single production center.

Another feature is the presence of reactions at the glaze/body interface (30-100 $\mu \mathrm{m}$ thick) in 200-500 $\mu \mathrm{m}$ thick glazes. This thick interface and the large density of bubbles are the signature of a probable single firing also invoked for the Portuguese tiles. ${ }^{33,34} \mathrm{We}$ made similar observations especially for clear purple, beige and green glazes (Fig. S7b). The interface reactions depend on firing conditions and clay-glaze compositions; they are much smaller with fired clay than with raw body (single firing). ${ }^{35}$ All these observations place the arista ceramics form the Alcazar Palace in the Hispano-Moresque tradition, far from the majolica style. 


\section{(2.2) Majolica ceramics}

Pisano brought majolica technology to Seville. The introduction of this technique strongly modified tile production; it allowed painting directly onto flat tiles covered with an opaque white. The artists were then able to represent a much larger number of figurative themes and to apply painting techniques such as perspective in their compositions. The Altarpiece (1504) is a remarkable example of such possibilities: fine modulations of colors and shadow effects give depth and volume to the central scene. In this work of art Pisano combines great expertise in the fabrication of tiles to achieve shadows and color effects usually associated with easel paintings. ${ }^{26}$

The following massive use of majolica in Seville took place in 1578 when Augusta covered the Palacio Gotico with tiles with repetitive decorative motifs. The two sets of majolica ceramics are different in typology $y^{10}$ and composition. It is interesting to compare their glaze microstructures and chemistries in an attempt to relate them to other analyses on tiles attributed to Pisano $^{12}$ and on majolica objects, ${ }^{5,7}$ as well as on fifty Italian ceramic objects produced during the $14^{\text {th }}-16^{\text {th }}$ centuries, as reviewed by Tite. ${ }^{6}$ Tite noted that double layer glazes were common in the $16^{\text {th }}$ century, with $300-600 \mu \mathrm{m}$ thick glazes similar to those observed by Antonelli et al. ${ }^{7}$ for nineteen $15^{\text {th }}-16^{\text {th }}$ century ceramics. A thin transparent layer (coperta) was frequently added on yellow glazes in Italy at that time. ${ }^{5,7}$

With reference to the Pisano altarpiece, comparisons of surface (Sn-L) and in-depth (Sn-K) concentrations (Table 1) indicate the presence of inner opaque layers containing cassiterite particles compatible with the presence of transparent copertas. Moreover the analysis by Gomez et al. ${ }^{12}$ of a couple of tile fragments attributed to Pisano (in the Royal oratory, no sample could be taken) suggests that he was using in 1504 the double layer glaze technique. The glaze chemistry of the Altarpiece is similar to that of these tile fragments except for $\mathrm{PbO}$ contents that are much lower in the tile fragments than in the altarpiece ( $32 \mathrm{wt} \% \mathrm{PbO})$. The first tile (Nic1) contains $25 \mathrm{wt} \% \mathrm{PbO}$ that is close to those in the $15^{\text {th }}-16^{\text {th }}$ century production of northern and central Italy. ${ }^{6}$ The second fragment ${ }^{11}$ (Nic2), with a $\mathrm{PbO}$ content quite common in majolica glazes $(17 \mathrm{wt} \%),{ }^{6}$ is identical to tiles on the lower sides of the Altarpiece (fig. 1). It is likely that for such a peripheral zone, Pisano relied on a low $\mathrm{Pb}$ content recipe for tile production. The high $\mathrm{Pb}$ content in the Altarpiece may suggest a link with $15^{\text {th }}$ century majolicas from Tuscany that have $28-34 \mathrm{wt} \% \mathrm{PbO}$ (Table 4 in Tite). ${ }^{6}$ A more advanced 
comparison of the chemistries of the Seville majolicas with the Italian majolicas would be desirable. However, it does not make sense to do it in view of our limited amount of data and of the extent of the concentration ranges reported, ${ }^{6}$ in particular for productions in a restricted time-period (mid $15^{\text {th }}$-early $16^{\text {th }}$ century) and location (Urbino and Pesaro, $36 \mathrm{~km}$ apart). ${ }^{7}$

The glazes of the Palacio Gotico tiles have generally a single layer except for double layer yellow/orange glazes as shown by SEM on cross-sections. The double layer glazes seem to become less frequent in Italy at the end of the $16^{\text {th }}$ century, ${ }^{6}$ a change that probably had not reached Augusta, because he learned the technique from a potter coming from Antwerp. Our observations did not reveal the existence of copertas; this is not surprising for such a massive production of tiles.

At first glance, two sets of majolica tiles can be distinguished in the Alcazar; the Pisano Altarpiece (early $16^{\text {th }}$ ) and the Augusta wall tiles (late $16^{\text {th }}$ ). Differences exist also between the two rooms of the Palacio Gotico attributed to Augusta. The small room glazes contain more $\mathrm{Sn}-\mathrm{K}$ and less $\mathrm{Sb}$ than the large room. Their $\mathrm{Pb}$-silicate glass basis is of the same type, $\mathrm{Pb}$ being lower and $\mathrm{K}$ higher (26 wt\% $\mathrm{PbO}, 3-10 \mathrm{wt} \% \mathrm{~K} 2 \mathrm{O}$ ) than in the Altarpiece glazes (32 $\mathrm{wt} \% \mathrm{PbO}, 4 \mathrm{wt} \% \mathrm{~K} 2 \mathrm{O})$. Cristobalite has been found by XRD only in the small room and $\mathrm{Pb}$ silicate crystals only in the large room. If the two sets of tiles have been produced in Augusta's workshop, different recipes have been used (supplementary information). It is worth mentioning that the name of Augusta appears in many places in the large room, but is absent in the small room. The origin of this difference is unknown.

The coloring agents are similar in the different majolicas that have been investigated, in accordance with the existing literature: blue and green colors are obtained with $\mathrm{Co}$ and $\mathrm{Cu}$. Green hues has been modified by the addition of $\mathrm{Pb}$ antimonate pigments in the Augusta tiles, an addition frequent in Della Robbia ceramics. ${ }^{6,27}$ Yellow/orange colors are due to $\mathrm{Pb}$ antimonate particles. We conclude with a few comments on blue and yellow glaze chemistries, two colors that are markers for process evolution.

Blue glazes contain Co that corresponds to $1 \mathrm{wt} \% \mathrm{CoO}$ in the Altarpiece, up to $1.8 \mathrm{wt} \% \mathrm{CoO}$ in the small room of the Palacio Gotico. These values are consistent with those of Tite, ${ }^{6}$ from 0.2 to $2.8 \mathrm{wt} \% \mathrm{CoO}$, and of Antonelli et al. ${ }^{7}$, from 0.6 to $1.3 \mathrm{wt} \% \mathrm{CoO}$. Such concentration variations correlate with hue variations. Blue glazes in the Palacio Gotico contain As and Bi, 14 
none of these elements being found in the Altarpiece. This is in agreement with the work on the origin of As and Bi in Della Robbia blues after $1520 .{ }^{29}$ Tite $^{6}$ and Antonelli et al. ${ }^{7}$ have made similar observations. This shows that the potters in Seville had the same cobalt suppliers as those in Italy (also for arista blues in 1543-46), cobalt ore discoveries in Spain dating from the $18^{\text {th }}$ century. ${ }^{36}$

Yellow pigments are based on $\mathrm{Pb}_{2} \mathrm{Sb}_{2} \mathrm{O}_{7}$ (Naples yellow) that can dissolve ions from the glaze or be doped to modify the color (orange, brown ...). Pb-antimonate has been known since ancient Egypt ${ }^{5,23}$ although it is not present in Europe between the $4^{\text {th }}$ and the $15^{\text {th }}-16^{\text {th }}$ centuries. It was used in the earliest majolica's after its re-introduction to the glass-makers in Venice. ${ }^{5}$ From XRD, we have ascribed the yellow pigments in the Palacio Gotico to $\mathrm{Pb}_{2} \mathrm{SnSbO}_{6.5}$ (supplementary information). In addition to $\mathrm{Sn}$, that is everywhere in majolica glazes, $\mathrm{Zn}$ can be added to the pigment and can also enter the $\mathrm{Pb}_{2} \mathrm{Sb}_{2} \mathrm{O}_{7}$ lattice and substitute for $\mathrm{Sb}$, as demonstrated in Renaissance majolicas from Pesaro. ${ }^{28} \mathrm{Zn}$ has been detected in the tiles analyzed by Gomez et al. ${ }^{12}$ using XRF (3.5 wt\% $\mathrm{ZnO}$ ) and SEM-EDX (3-4 wt\% ZnO). In the present work, $\mathrm{ZnO}$ concentrations from $1 \mathrm{wt} \%$ in the Altarpiece up to $6 \mathrm{wt} \%$ in the Palacio Gotico (large room) have been found. Similar Zn concentrations at the glaze surface have been observed in majolica tiles (Louvre Museum, inventory number OA11798) from the Petrucci Palace in Sienna, dated from $1509,{ }^{37}$ that have been analyzed with the XRF-XRD and by PIXE. ${ }^{1,17,23}$ In these yellows, there are concentrations as high as $10 \mathrm{wt} \% \mathrm{ZnO}$, with almost no $\mathrm{Zn}$ in orange and green as in tables 1 and 2 . The best way to understand the role of $\mathrm{Zn}$ in these yellow glazes would be to analyze the $\mathrm{Pb}$-antimonate pigments and glaze matrices at the cost of taking samples from the artworks. Indeed, we detected Zn by SEM-EDX in a few yellow pigment particles in a sample from the Palacio Gotico (fig S5). In spite of the abundant literature, ${ }^{4,5,27,28}$ more studies are necessary to fully understand $\mathrm{Zn}$ in $\mathrm{Pb}$-Sb-yellow glazes

\section{Conclusions}

Portable XRF analysis is fast and allowed us to study $16^{\text {th }}$ century tiles from the walls (about $600 \mathrm{~m}^{2}$ ) of the Alcazar Palace in Seville when only a few micro-samples could be analyzed by optical and electron microscopies which has, however, the advantage of examining crosssections. Two portable XRF systems have been used that could allow to obtain quantitative results thanks to a careful data treatment. 
The arista tiles are traditional ceramics from the Iberian Peninsula with their typical chemistry and microstructure (transparent glazes, Fe yellow). They seem to be single fired. $16^{\text {th }}$ century Arista glaze color recipes were not influenced by those used for majolicas which reached their 'Golden Age' in Italy at this time.

The Seville majolicas have three specific compositions although they are believed to have been produced by two artists, Pisano (1504) and Augusta (1578). Results suggest that Augusta may have subcontracted part of the task in view of the size of the Alcazar work. Relations to Italian production are obvious.

More studies would be useful including improved non-destructive analysis on glazes and bodies (XRF of light elements - Na, Al, etc. - thanks to helium between detector and artwork $;^{17}$ high resolution SEM and quantitative EDX on cross-sections, etc.). Finally, historical information on the organization of $16^{\text {th }}$ century mass production of the tiles in Seville would be profitable.

\section{ACKNOWLEDGEMENTS}

The authors have a special thought for the late Hélène Rousselière who participated in the work and untimely passed away. Many thanks to Dr W.G. Fahrenholtz, Editor in Chief, and to Helen Glanville who helped in improving the text. The XRD/XRF analysis in the Alcazar was performed within the MOLAB access activity of the EU FP7 program (CHARISMA, Grant 228330). We are indebted to the Patronato de los Reales Alcazares de Sevilla for their collaboration with our investigation.

\section{REFERENCES}

1. Garofano I, Robador MD, Perez-Rodriguez JL, Castaing J, Pacheco C, Duran A. Ceramics from the Alcazar Palace in Seville (Spain) dated between the $11^{\text {th }}$ and $15^{\text {th }}$ centuries: compositions, technological features and degradation processes. J Eur Ceram Soc. 2015; 35:4307-4319.

2. Sancho Corbacho A. La cerámica Andaluza, Casa de Pilatos (Andalusian ceramics, Casa de Pilatos), Fundación Casa Ducal de Medinacelli (Spain) 2008.

3. Cruiskshank G, Gonzalez E. A history of tile making in Spain, part II, Paradise Lost. Tile Today. 1998;72-78.

4. Bultrini G, Fragala I, Ingo GM, Lanza G. Characterization and reproduction of yellow pigments used in central Italy for decorating ceramics during the Renaissance. App Phys A. 2006; 83:557-565.

5. Chiarantini L, Gallo F, Rimondi V, Benvenuti M, Costagliola P, Dini A. Early Renaissance production recipes for Naples Yellow pigments: a mineralogical and lead isotope study of Italian Majolica from Montelupo (Florence). Archaeometry 2015; 57:879-896.

6. Tite MS. The production technology of Italian maiolica: a reassessment. J Archaeol Science. 2009; 
7. Antonelli F, Ermati AL, Verita M, Raffaeli G. An archaeometric contribution to the characterization of Renaissance maiolica from Urbino and a comparison with coeval maiolica from Pesaro (the Marches, Central Italy). Archaeometry 2014; 56:784-804.

8. Barbe F. Majolique : l'âge d'or de la faïence italienne au XVIe siècle, Paris :Editions Citadelles \& Mazenod; 2016.

9. Malo Cerro M. Azulejería en Castilla y León: de la edad media al modernismo, Thesis University of Valladolid; 2001

10. Pleguezuelo A. A palace of tiles. Apuntes del Alcazar de Sevilla 2013;14:346-354.

11. Pleguezuelo A. Niculoso Pisano and the Real Alcazar of Seville. Apuntes del Alcazar de Sevilla 2012;13:62-71.

12. Gomez A, Polvorinos del Rio A, Castaing J, Pleguezuelo A. Ceramics by Niculoso Pisano and quantitative analysis of glazes using portable XRF. ph investigación 2016; 6:1-23.

13. Dumortier C. Frans Andries, ceramista de Amberes en Sevilla. Laboratorio de Arte 1995;8:51-60.

14. Lupion Alvarez JJ, Arjonilla Alvarez M, Ruiz-Conde A, Sanchez Soto PJ. Frontal del altar y paneles cerámicos del siglo XVI en la Iglesia del Convento de Madre de Dios (Sevilla): estado de conservación y reconstrucción virtual. Cerámica y Vidrio 2006; 45:305-313.

15. Menendez de Luarca LRL. Alcoba y cuadra, dos sinónimos para un arquetipo de origen persa. Oppidum, Universidad SEK Segovia 2006; 2:117-140.

16. Castro Fuertes J. Los revestimientos ceramicos en el Pabellon de Carlos V del Real Alcazar de Sevilla, Thesis University of Seville; 2016.

17. Gianoncelli A, Castaing L, Bouquillon A, Polvorinos A, Walter P, Quantitative elemental analysis of Della Robbia glazes with a portable XRF spectrometer and its comparison to PIXE methods. X-ray Spectrom. 2006; 35:365-369.

18. Gianoncelli A., Castaing J, Ortega L, Dooryhée E, Salomon J, Walter P, et al. A portable instrument for in-situ determination of the chemical and phase composition of cultural heritage objects. X-Ray Spectrom. 2008; 37:418-423.

19. Eveno M, Moignard B, Castaing J. Portable apparatus for in situ X-ray diffraction and fluorescence analyses of artworks. Microscop Microanal. 2011; 17:667-673.

20. Simsek G, Casadio F, Colomban P, Bellot-Gurlet L, Faber KT, Zelleke G, et al. On-site identification of early Böttger red stoneware made at Meissen using portable XRF: 1 body analysis. J Am Ceram Soc. 2014; 97:2745-54.

21. Simsek G, Colomban P, Casadio F, Bellot-Gurlet L, Zelleke G, Faber KT, et al. On-site identification of early Böttger red stoneware made at Meissen using portable XRF: 2 Glaze and gilding analysis. J Am Ceram Soc. 2015;98:3006-13.

22. Robador MD, de Viguerie L, Perez-Rodriguez JL, Rousselière H, Walter P, Castaing J. The structure and chemical composition of wall paintings from Islamic and Christian time in the Seville 
23. de Viguerie L, Duran A, Bouquillon A, Solé VA, Castaing J, Walter Ph. Quantitative X-ray fluorescence analysis of an ancient Egyptian pendant and comparison with PIXE. Anal Bioanal Chem. 2009;395:2219-2225.

24. Solé VA, Papillon, Cotte M, Walter P, Susini J, A multiplatform code for the analysis of energydispersive X-ray fluorescence spectra. Spectrochim Acta Part B 2007;62:63-68.

25. Tite M, Pradell T, Shortland A. Discovery, production and use of tin-based opacifiers in glazes, enamels and glazes from the late iron age on-wards: a reassessment. Archaeometry 2008;50:67-84.

26. de Viguerie L, Walter Ph, Laval E, Mottin B, Solé VA. Revealing the sfumato technique of Leonardo da Vinci by X-Ray Fluorescence spectroscopy. Angew Chem. 2010;122:1-5.

27. Duran A, Castaing J, Lehuédé P, Bouquillon A. Les pigments jaunes des glaçures de l'atelier Della Robbia. In : Zucchiatti A, Bouquillon A, Bormand M, editors. Della Robbia. Dieci anni di Studi - Dix ans d'études. Genova : Sagep éditor, 2011; p 44-49.

28. Cartechini L, Rosi F, Miliani C, D'Acapito F, Brunetti BG, Sgamelotti A, Modified Naples yellow in Renaissance majolica: study of $\mathrm{Pb}-\mathrm{Sb}-\mathrm{Zn}$ and $\mathrm{Pb}-\mathrm{Sb}-\mathrm{Fe}$ ternary pyroantimonate by $\mathrm{X}$-ray absorption spectroscopy. J Anal At Spectrom. 2011;26:2500-2507

29. Zucchiatti A, Bouquillon A, Katona I, D'Alessandro A. The Della Robbia blue: a case study for the use of cobalt pigments in ceramics during the Italian Renaissance. Archaeometry 2006;48:131152.

30. Bouquillon A, Barbe F, Lehuédé P, Castaing J, Crépin-Leblond T. Bernard Palissy: scientist and potter of the Renaissance in France. In: Saunders D, Springs M, Meek A, editors. Proceedings of the Renaissance workshop. London: Archetype Pub. Ltd 2013; p 152 - 159.

31. Walton M, Trentelman K, Cianchetta I, Maish J, Saunders D, Foran B, et al. Zn in Athenian black gloss ceramic slips: a trace marker element for fabrication technology. J Am Ceram Soc. 2015;98:4306.

32. Tite MS. Iznik pottery: an investigation of the methods of production. Archaeometry 1989;31:115132.

33. Coentro S, Alves LC, Relvas C, Ferreira T, Mirao J, Molera J, et al. The glaze technology of hispano-moresque ceramic tiles: a comparison between Spanish and Portuguese collections. Archaeometry 2017;59:667-84.

34. Coentro S, Trindade RAA, Mirão J, Candeias A, Alves LC, Silva RMC, et al. Hispano-Moresque ceramic tiles from the Monatery of Santa Clara-a-Velha (Coimbra, Portugal). J Archaeol Sci. 2014;41:21-8.

35. Molera J, Pradell T, Salvadò N, Vendrell-Saz M. Interactions between clay bodies and lead glazes. J Am Ceram Soc. 2001;84:1120-1128

36. Rubio Navas J. Monografia sobre recursos minerales de cobalto en España (Monograph on mineral resources in Spain). Madrid: Instituto Geològico y Minero de España; 2003.

37. Bouquillon A, Lehuédé P. Carreaux Petrucci Renaissance et modernes (Renaissance and modern 
Petrucci tiles) - Musée du Louvre. Paris : Compte-rendu d'étude C2RMF n 20817; 2010. 


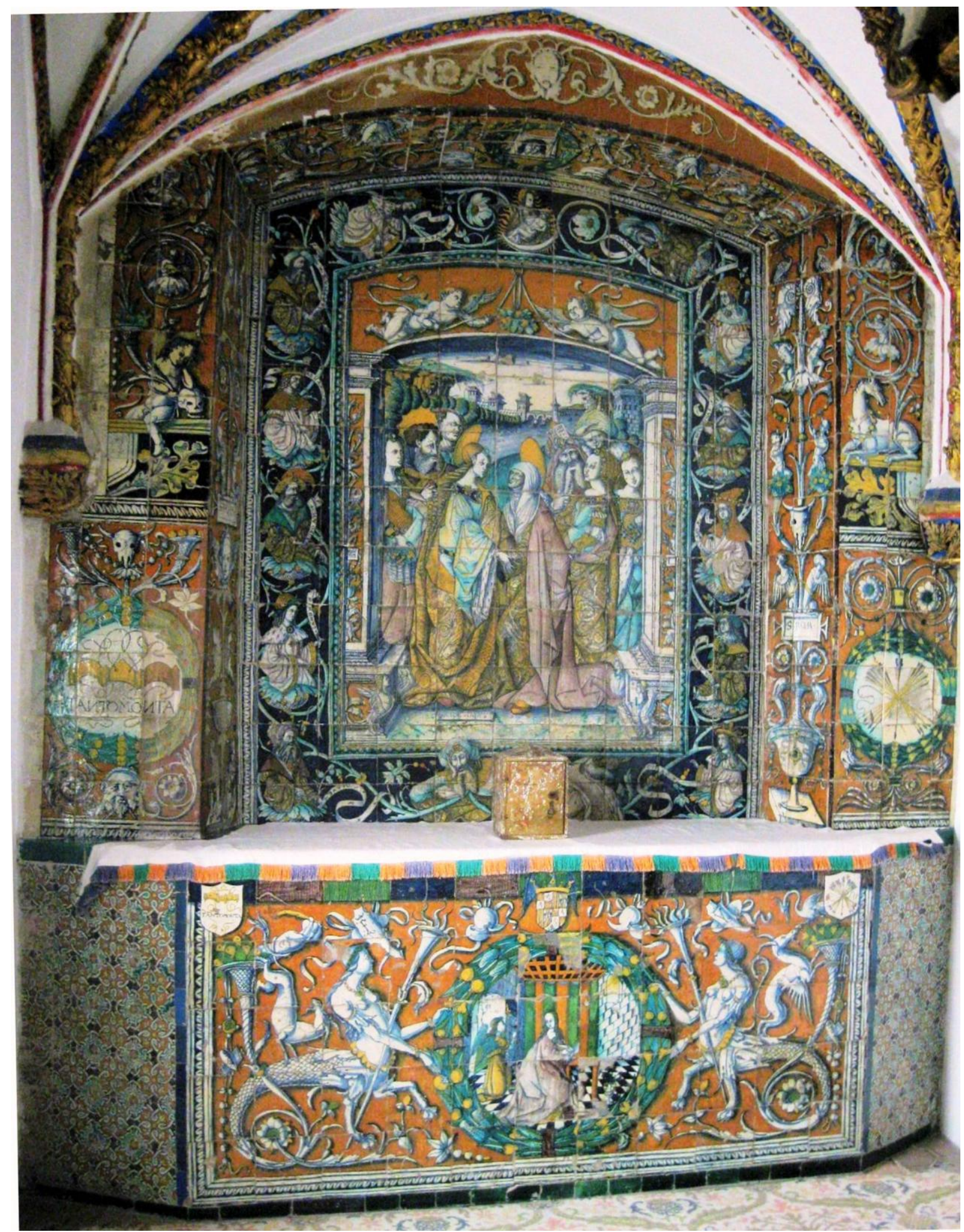

Fig 1: Majolica Altarpiece, made by Niculoso Pisano, located in the oratory of the Royal apartments. The Altarpiece is about $4 \mathrm{~m}$ high. The work is signed "NICULOSO FRANCISCO ITALIANO ME FECIT, 1504" 11,14 Most of the XRF has been performed on the Annunciation (center of lower part) and the Visitation (main scene of upper part). A few points have been analyzed on the left pillar, side and front (coat of arms). The tile studied by Gomez et al. ${ }^{12}$ corresponds to the lowest extreme right and left panels. 


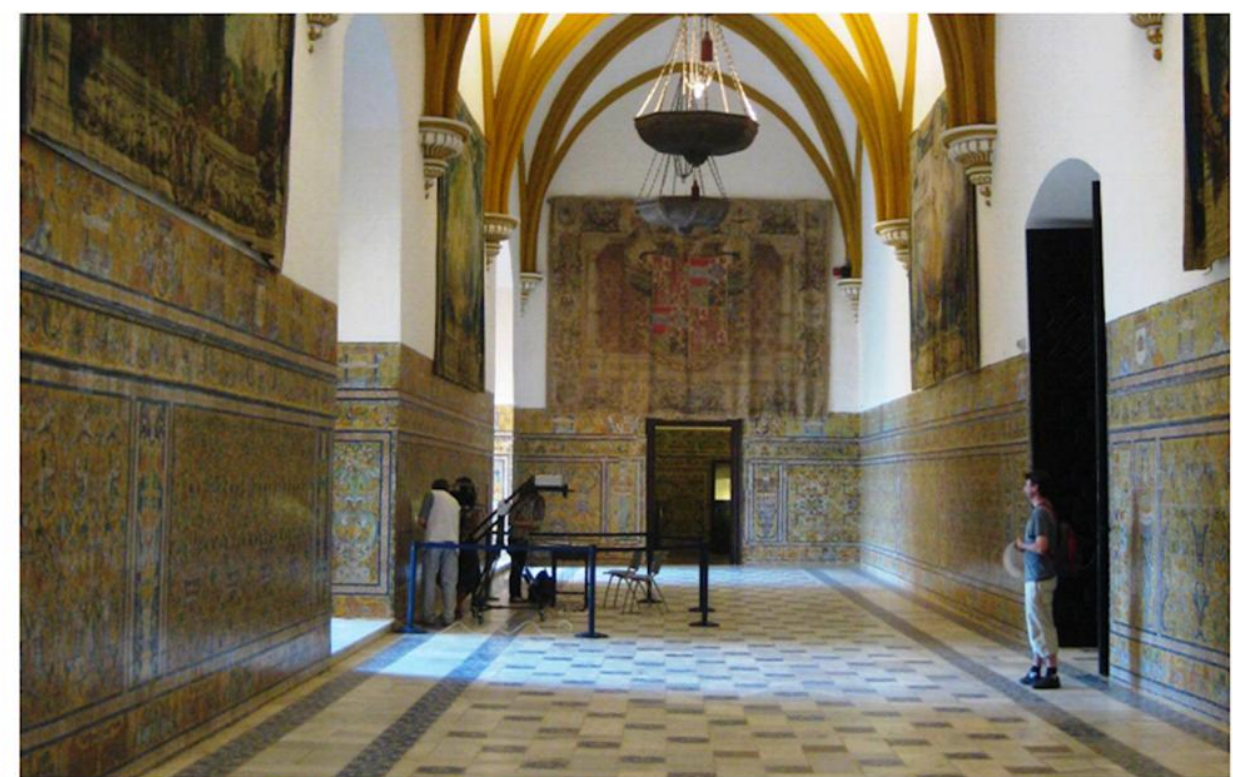

Figure 2a

Figure $2 \mathrm{~b}$
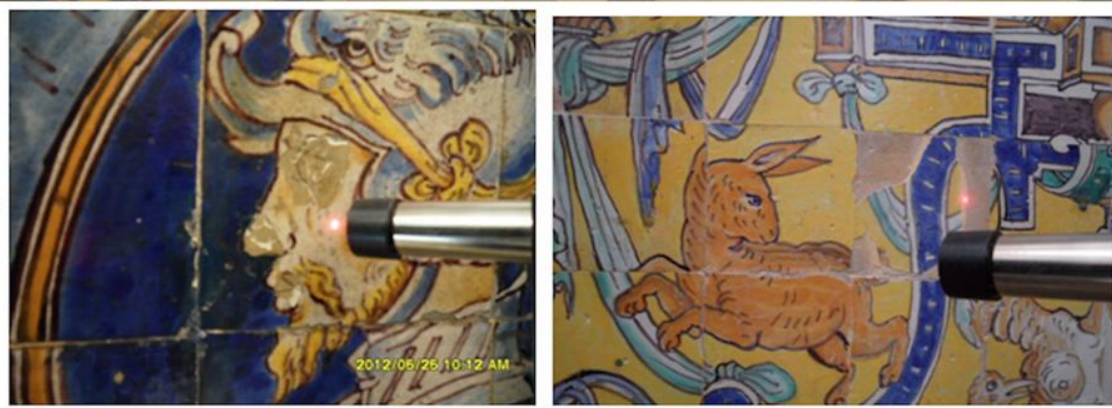

Figure $2 c$

Fig. 2: Palacio Gotico (a) view of the large room with the team at work on the left; (b) tiles showing a portrait of Carlos Quinto; the tip of the $\mathrm{X}$ ray detector ( $2 \mathrm{~cm}$ diameter) is next to the measurement point indicated by a laser impact; (c) tiles in the small room. Yellow, orange and blue colors can be seen. 

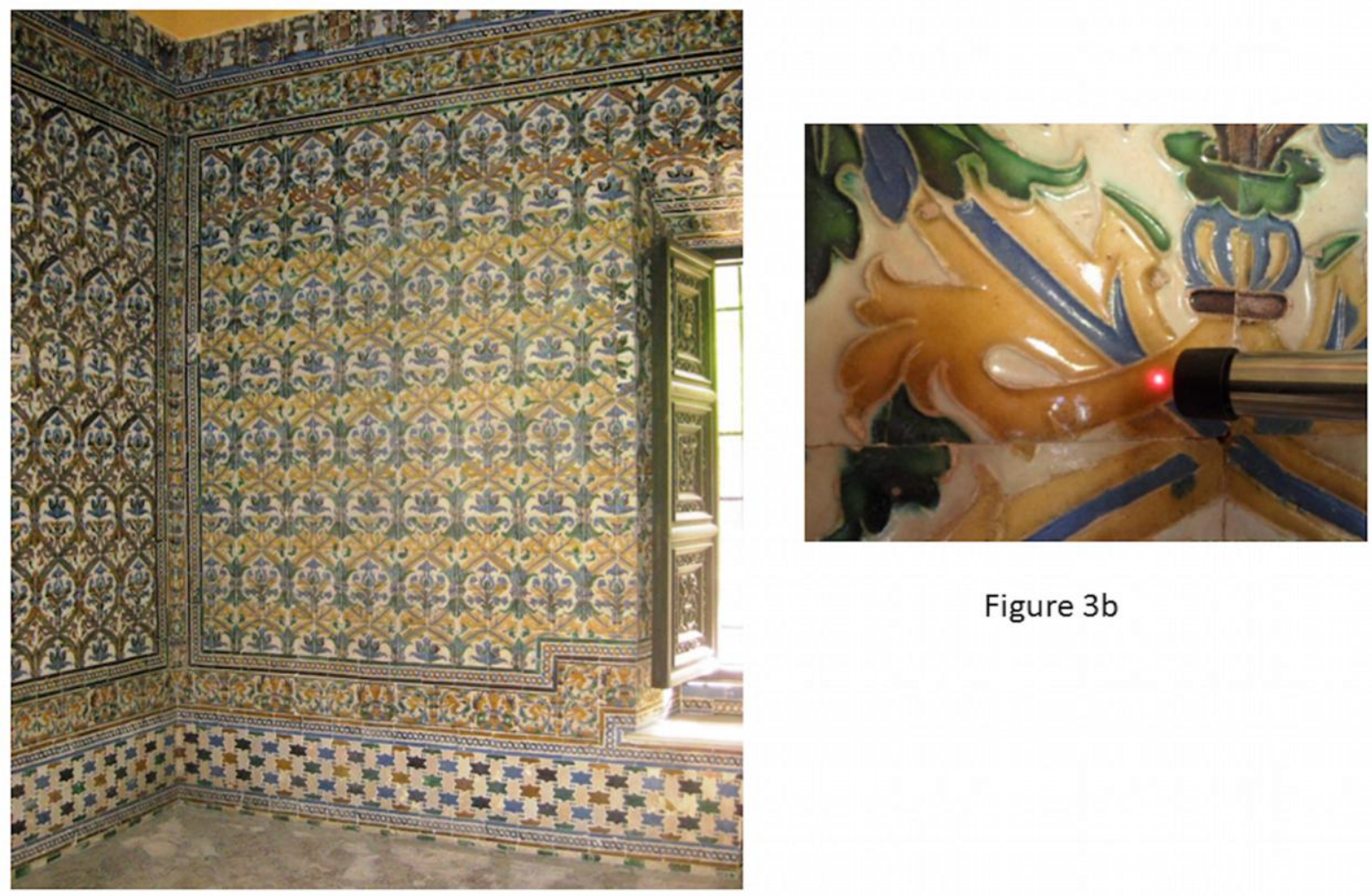

Figure $3 b$

Figure $3 a$

Fig. 3: (a) Cenador de Carlos Quinto: inside view ; there is $4 \mathrm{~m}$ between the corner and the window. Note the color variation from yellow on the right to brown-beige on the left, possibly due to poor control of the ceramic processing. (b) close view of arista tiles during a measurement. 


\section{TECHNOLOGICAL EVOLUTION OF CERAMIC GLAZES IN THE RENAISSANCE: IN- SITU ANALYSIS OF TILES IN THE ALCAZAR (SEVILLE, SPAIN)}

\section{SUPPLEMENTARY INFORMATION}

\section{Experimental details and method for quantitative analysis with PyMca software}

XRF spectra (fig. S1) are simulated with the PyMca software in order to deduce the concentrations of the various elements. PyMca has been developed at the ESRF (http://pymca.sourceforge.net/index.html). ${ }^{24}$ It has been used a few times for the study of ceramic glazes. ${ }^{12,17,23}$

The PyMca parameters have been refined analyzing a $16^{\text {th }}$ century piece of ceramics for the calculation of element concentrations from both XRF-XRD and Pd-XRF spectra. The DR1 XRF spectra have been collected various times, in particular after each displacement of the systems from one room to another in the Alcazar.

DR1 composition had been previously determined by PIXE in an ion accelerator ${ }^{17,23}$ and by SEM-EDX (unpublished). The results are in good agreement (table S1); DR1 is a good secondary standard (fig. S2). The concentrations were calculated with the PyMca fundamental parameter method under the assumption of homogeneous glazes as in DR1 ${ }^{17}$ as well as in other Della Robbia ceramics. ${ }^{6,17}$ The concentration values are not normalized to $100 \mathrm{wt} \%$ as for PIXE and SEM-EDX. The PyMca concentrations are absolute in the frame of DR1 values (table S1) and, then, do not depend on the accuracy of the values for light elements.

Table S1: Composition of DR1 (Della Robbia blue glaze) as measured by PIXE on the surface and by SEM on a cross-section sample. The glaze is homogeneous through its $100 \mu \mathrm{m}$ thickness. Examples of values calculated with PyMca from spectra with XRF-XRD (DR1_08) and Pd-XRF (DR1_Pd).

\begin{tabular}{|l|l|l|l|l|l|l|l|l|l|l|l|l|l|}
\hline & $\mathrm{Na}_{2} \mathrm{O}$ & $\mathrm{MgO}$ & $\mathrm{Al}_{2} \mathrm{O}_{3}$ & $\mathrm{SiO}_{2}$ & $\mathrm{~K}_{2} \mathrm{O}$ & $\mathrm{CaO}$ & $\mathrm{Fe}_{2} \mathrm{O}_{3}$ & $\mathrm{CoO}$ & $\mathrm{NiO}$ & $\mathrm{CuO}$ & $\mathrm{Zn0}$ & $\mathrm{SnO}_{2}$ & $\mathrm{PbO}$ \\
\hline PIXE & $\mathbf{3}$ & $\mathbf{0 . 4}$ & $\mathbf{2 . 7}$ & $\mathbf{4 8}$ & $\mathbf{2 . 1}$ & $\mathbf{3 . 7}$ & $\mathbf{2}$ & $\mathbf{0 . 5 5}$ & $\mathbf{0 . 2}$ & $\mathbf{0 . 1 5}$ & $\mathbf{0 . 0 5}$ & $\mathbf{1 3}$ & $\mathbf{2 3}$ \\
\hline SEM-EDX & 2.4 & 0.5 & 2.7 & 47 & 2.85 & 4.7 & 2.3 & 0.53 & 0.15 & & 0.1 & 13.2 & 23.3 \\
\hline DR1_08 & & & & 45 & 2.1 & 4 & 2.1 & 0.52 & 0.64 & 0.25 & 0.02 & $15(\mathrm{~K})$ & $26(\mathrm{~L})$ \\
\hline DR1_Pd & & & & 49.5 & 2.05 & 3.2 & 1.9 & 0.51 & 0.22 & 0.18 & 0.01 & $11.7(\mathrm{~K})$ & $23.2(\mathrm{~L})$ \\
& & & & & & & & & & & & $12.1(\mathrm{~L})$ & $25.2(\mathrm{M})$ \\
\hline
\end{tabular}

Measurements have been performed on tiles in the Alcazar Palace that are on vertical 
surfaces, perpendicular to the floor. The reproducibility of the data is related to the position accuracy of the systems that is achieved by controlling distance and angle between the XRF apparatus and the tiles. The distance is determined by the superposition of two laser spots. ${ }^{17,19}$ The accuracy on the object XRF-detector distance is equivalent for both systems $(0.2-0.3$ $\mathrm{mm}$ error for $10-25 \mathrm{~mm}$ distances). The angle is estimated by the operator. However, consequences on the XRF spectra strongly depend on the geometry which differs between Pd$\mathrm{XRF}$ and $\mathrm{XRF}-\mathrm{XRD}$. For the Pd-XRF, the XRF-detector is perpendicular to the tile surface that is irradiated by a beam at $45^{\circ}$; only large offsets from these angles can alter the XRF spectra. For the XRF-XRD system, the beam is at $10^{\circ}$ from the surface; then, an error on the object XRF-detector distance induces a strong displacement of the X-ray spot away from the XRF-detector axis, with consequences on spectra especially at low energies (less than $3 \mathrm{keV}$ ) because of X-ray absorption in air and in the plastic collimator (mechanical protection of the detector window). This is also true in case of error on the beam-surface angle, especially for values less than $10^{\circ}$. Such angular error is likely to happen with DR1 that is small (fig. S2) compared to the XRF-XRD apparatus. ${ }^{18,19}$ An angular error does not happen in front of the tiles because the frame of the system (cuboid of more than $50 \mathrm{~cm}$ sizes) is easily placed parallel to the wall. ${ }^{19} \mathrm{We}$ have observed such dispersions on low energy DR1 spectra (see below) that are barely discernible for measurements on wall tiles (fig. S1).

The whole procedure of PyMca parameter definition has been presented by de Viguerie. ${ }^{23}$ The X-ray sources have been defined thanks to direct measurements and then by optimization on standards. For Pd-XRF, the object XRF-detector distance was $17 \mathrm{~mm}$ in air and the X-ray flux was $2.9 \times 10^{7}$ photons/second. The relative errors on most concentrations values for DR1 are less than $10 \mathrm{wt} \%$, with some fluctuations from one day to the other requiring parameter adjustments. However, $\mathrm{Si}, \mathrm{Ca}$ and $\mathrm{Sn}-\mathrm{L}$ have differences with respect to nominal values which can have various origins. At the energy of Si-K (1.7 keV) absorption varies rapidly for 1 to $3 \mathrm{~cm}$ in air, errors in position inducing XRF intensity variations. Here, the Sn-L concentration value has to be multiplied by 1.7-2 and errors as large as $20 \mathrm{wt} \%$ on $\mathrm{CaO}$ have been found, which would suggest a problem in the calculations of $\mathrm{Ca}-\mathrm{K}(3.7$ and $4 \mathrm{keV}$ ) and $\mathrm{Sn}-\mathrm{L}$, lines (from 3 to $3.8 \mathrm{keV}$ ). However, the quality of this de-convolution has been demonstrated in a soda lime glass ${ }^{23}$ containing $\mathrm{Ca}$ and $\mathrm{Sn}$. We have thus corrected directly Sn-L concentration values without modification on PyMca parameters. For the XRF-XRD 
system, we found some dispersion in the nine DR1 XRF spectra, especially at low energy. Four of these spectra showed good coincidence (3 to $13 \mathrm{wt} \%$ standard deviation on line intensities) indicating a correct positioning of DR1 in the XRF-XRD. The average spectrum was used to validate the choices for PyMca parameters. Various "filters" have been defined in the PyMca software: object XRF-detector distance $25 \mathrm{~mm}$ air; Be XRF-detector window 125 $\mu \mathrm{m}$; plastic XRF-detector collimator simulated by $85 \mu \mathrm{m}$ thick $\mathrm{NaCl}$ diaphragm, source with $15 \mu \mathrm{m} \mathrm{Ni}$ filter to eliminate $\mathrm{Cu}-\mathrm{K} \beta$ for XRD. A flux of $1.46 \times 10^{9}$ photons/second was obtained. With these conditions, the DR1 XRF spectrum was well fitted (fig. S3) and good concentration values were obtained after applying corrections on several elements.

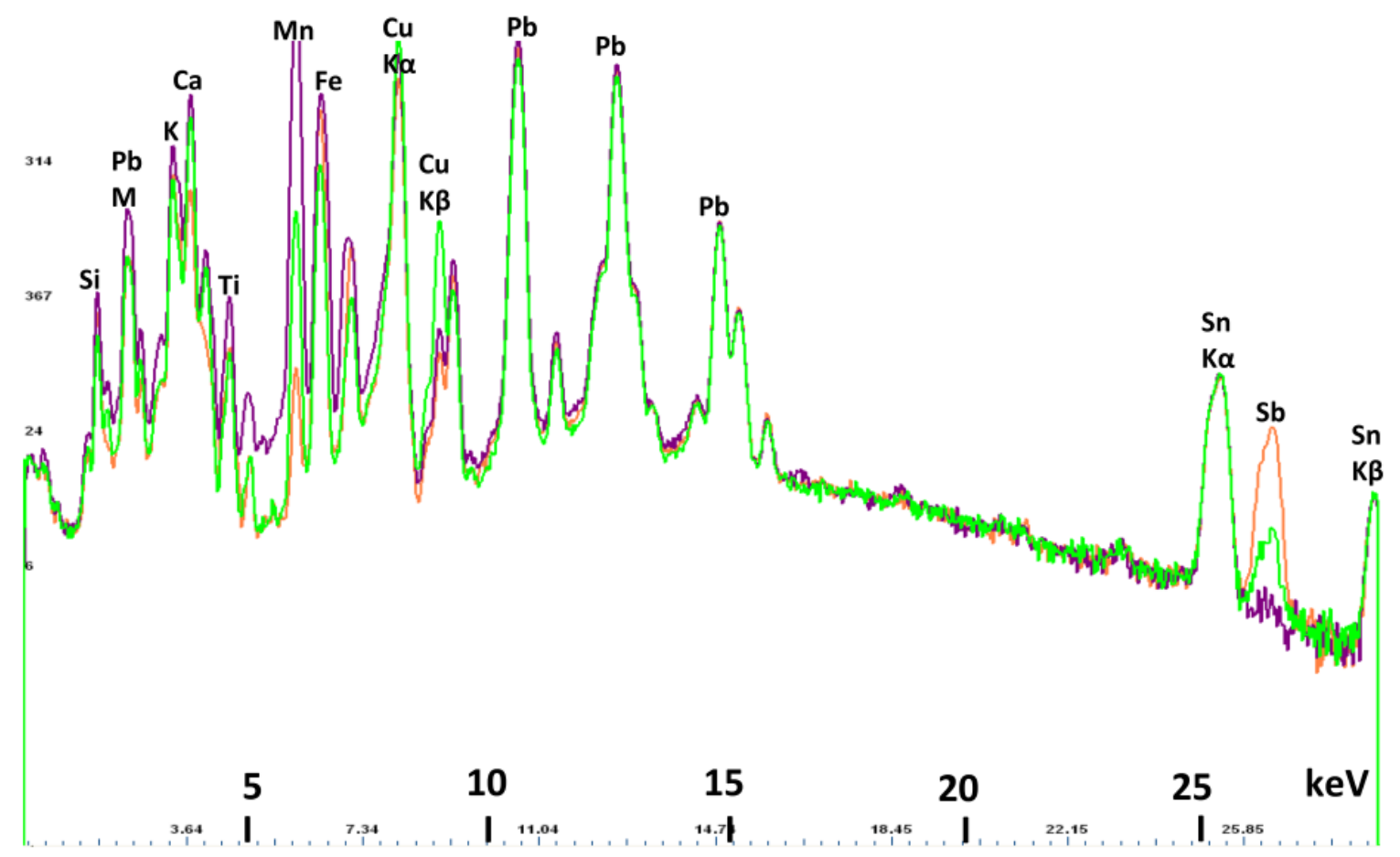

Fig. S1: XRF-XRD in the Palacio Gotico. XRF spectra plotted as log intensity versus X-ray energy. Lines are visible from $\mathrm{Si}$ to $\mathrm{Sn}-\mathrm{K} \beta$. There are spectra for three glaze colors: orange (with strong $\mathrm{Sb}$ line); green (with small Sb line and a strong $\mathrm{Cu}-\mathrm{K} \beta$ line); purple (with no $\mathrm{Sb}$ and a strong $\mathrm{Mn}$ line). Note that the rest of the line intensities are similar, except at low energies (different $\mathrm{Pb}-\mathrm{M}$ for identical $\mathrm{Pb}-\mathrm{L}$ ). $\mathrm{Cu}-\mathrm{K} \alpha(8.05 \mathrm{keV})$ is due to the source. Ni-K $\alpha(7.5 \mathrm{keV})$ was not calculated with PyMca because it is in the left foot of $\mathrm{Cu}-\mathrm{K} \alpha . \mathrm{Zn}-\mathrm{K} \alpha(8.6 \mathrm{keV})$ is between $\mathrm{Cu}-\mathrm{K} \alpha$ and $\mathrm{Cu}-\mathrm{K} \beta(8.9 \mathrm{keV})$; its concentration is found to be $0.3 \mathrm{wt} \% \mathrm{ZnO}$ in the green glaze. 


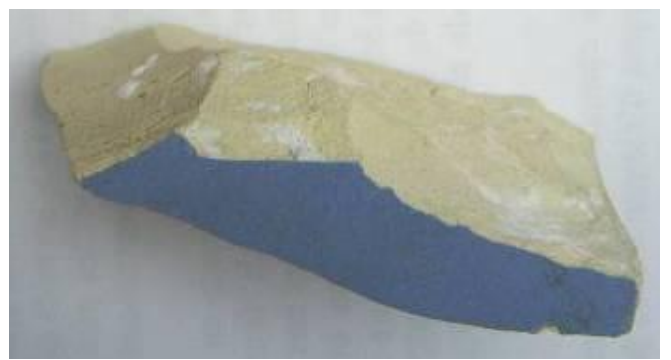

Fig. S2: DR1 is a Della Robbia shard used as a secondary standard for quantitative XRF analysis [17]: blue glaze on ceramic body. Dimensions about $3 \mathrm{~cm} \times 1 \mathrm{~cm}$.

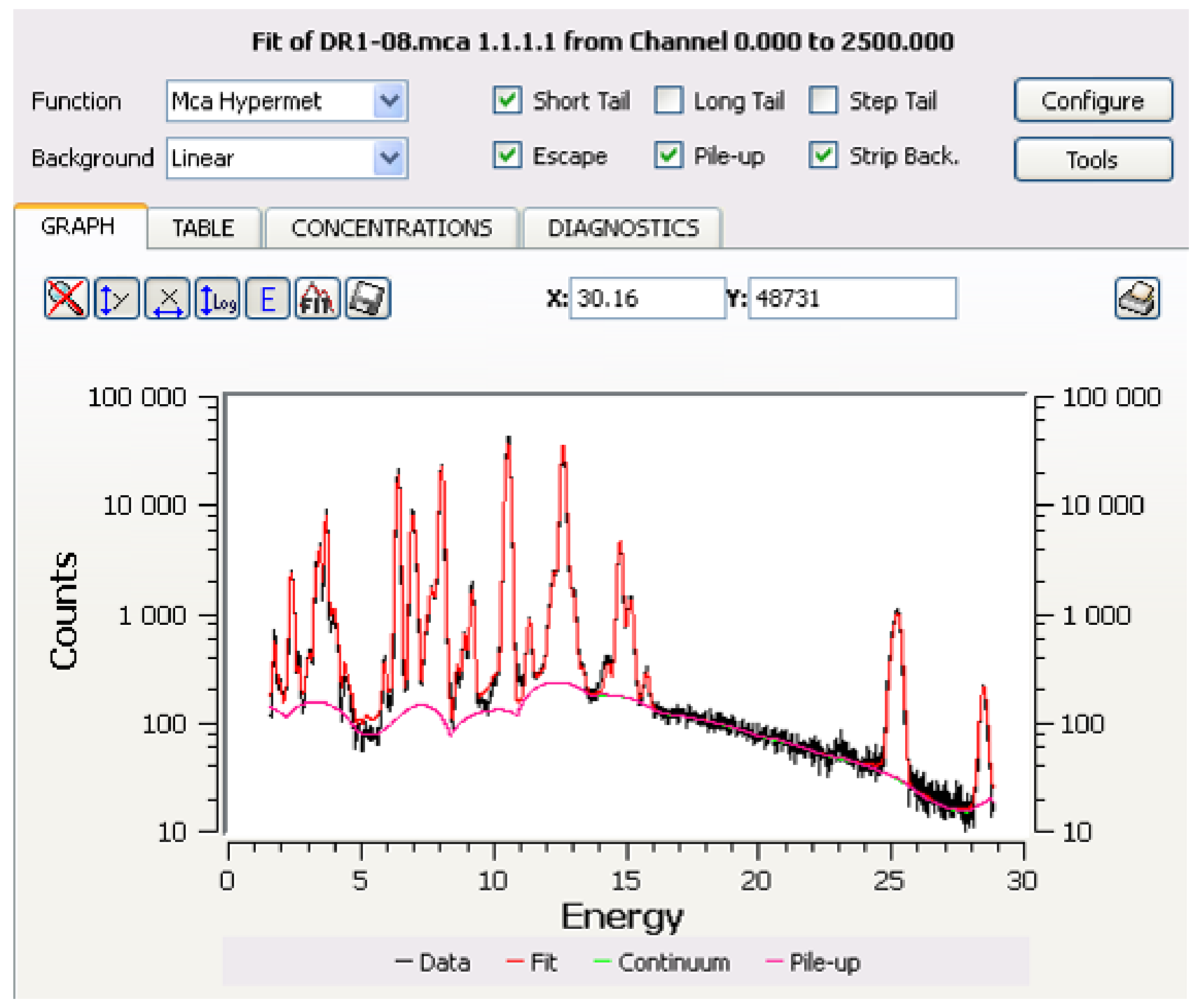

Fig. S3: XRF spectrum (log intensity versus energy) of DR1 (black line) and its comparison with the PyMca simulation (red line). The concentrations are given in table $\mathrm{S} 1$. Values for $\mathrm{NiO}$ and $\mathrm{CuO}$ are not good because of the strong $\mathrm{Cu}-\mathrm{K}$ line $(8 \mathrm{keV})$ from the source of the XRF-XRD. 


\section{XRD in the Palacio Gotico}

$\mathrm{XRD}$ is necessary to complement XRF and identify the various crystalline phases in artworks. ${ }^{18,19}$ Glazes are amorphous and may contain crystalline particles. XRD has been performed in the Palacio Gotico (five in the small room and seven (six) in the large room).

In a white glaze (fig. 2b), there is about $4 \mathrm{wt} \% \mathrm{SnO}_{2}$. XRD diagrams are dominated by quartz and cassiterite as expected for a white color. Quartz comes from un-fused raw materials.

Yellow, orange and green glazes contain $\mathrm{Sn}$ and $\mathrm{Sb}$ with about $7 \mathrm{wt} \% \mathrm{SnO}_{2}$ in the small room (fig. 2c) and $3 \mathrm{wt} \% \mathrm{SnO}_{2}$ in the large room (fig. 2a and b) for the three colors. The Sb content is more variable, with about $5.5 \mathrm{wt} \% \mathrm{Sb}_{2} \mathrm{O}_{5}$ in the small room and $7.5 \mathrm{wt} \% \mathrm{Sb}_{2} \mathrm{O}_{5}$ in the large room for yellow and orange glazes. For green glazes, there is about $1.5 \mathrm{wt} \% \mathrm{Sb}_{2} \mathrm{O}_{5}$ in both rooms. The three color XRD's are dominated by cassiterite, cristobalite and $\mathrm{Pb}$ antimonate in the small room (fig S4). Only the last compound dominates in the large room for yellow and orange glazes. Green glazes also contain $\mathrm{Pb}$ antimonate with no cristobalite in the small room and a little quartz in the large room. $\mathrm{Pb}$ antimonate XRD has been ascribed to $\mathrm{Pb}_{2} \mathrm{SnSbO}_{6.5}$ (fig S4). However, there are many possibilities of solid solutions based on $\mathrm{Pb}_{2} \mathrm{Sb}_{2} \mathrm{O}_{7}$ where $\mathrm{Sb}$ is substituted by $\mathrm{Sn}, \mathrm{Fe}$, and/or $\mathrm{Zn}$ with changes in the hues and small variations in the crystalline cell parameter. ${ }^{12,27,28}$ XRD was performed on the two Pisano tiles that suggested the presence of three types of $\mathrm{Pb}$-antimonate, (without and with $\mathrm{Zn}$ or Fe substitution; less than $0.5 \mathrm{wt} \%$ differences on crystalline parameters). ${ }^{12}$ The limited resolution of the portable XRF-XRD does not allow differentiating the various $\mathrm{Pb}$-antimonate yellow compositions according to their parameters. ${ }^{27}$

XRD diagrams for blue glazes are dominated by cristobalite, quartz and cassiterite in the small room. and by $\mathrm{Pb}$-silicates $\left(\mathrm{Pb}_{2} \mathrm{SiO}_{4} ; \mathrm{PbSiO}_{3}\right.$, etc) with a little quartz in the large room. Crystalline $\mathrm{Pb}$-silicates are easily formed below $700^{\circ} \mathrm{C}$ in the $\mathrm{Pb}-\mathrm{SiO}_{2}$ system (Schevchenko M, Jak E, 2018). In the blue tiles, it must be due to misfired glazes maintained during a long time between 600 and $700^{\circ} \mathrm{C}$.

The last color is purple with cassiterite and bixbyite $\left(\mathrm{Mn}_{2} \mathrm{O}_{3}\right)$ found in the large room and only cassiterite in the small room.

There are substantial differences in the tile manufacture between the small room (cristobalite) and the large room (bixbyite) although the glaze colors are similar. Cristobalite is a high temperature form of quartz. Experiments show that cristobalite is first to form above $900^{\circ} \mathrm{C}$ and that it is favored by the presence of $\mathrm{K}$ (Dapiaggi et al. 2015) that is in larger concentrations in the small room compared to the large room. The final amount of cristobalite 
can be controlled by adequate $\mathrm{Na}-\mathrm{K}$ content and time-temperature firing conditions (Dapiaggi et al. 2015). The presence of cristobalite in the small room could be due to a processing change in Augusta's workshop.

Finally, a few measurements have been made on the ceramic body in the small room where there are many glaze losses (fig. 1c). In most cases, we found almost only gypsum likely due to tentative consolidation with plaster. On clean body surfaces, the XRF compositions are consistent with those resulting from Seville clay ${ }^{1,12}$ with about $2 \mathrm{wt} \% \mathrm{~K}_{2} 0,20 \mathrm{wt} \% \mathrm{CaO}$ and 6 wt $\% \mathrm{Fe}_{2} \mathrm{O}_{3}$. XRD showed the presence of quartz, diopside $\left(\mathrm{Ca}_{2} \mathrm{MgSi}_{2} \mathrm{O}_{6}\right)$, gehlenite $\left(\mathrm{Ca}_{2} \mathrm{Al}_{2} \mathrm{SiO}_{7}\right)$ compatible with a body firing around $900^{\circ} \mathrm{C}$.

\section{References:}

Dapiaggi $\mathrm{M}$ et al. The formation of silica high temperature polymorphs from quartz: influence of grain size and mineralizing agents. J Europ Ceram Soc. 2015;35:4547-55.

Schevchenko M, Jak E, Experimental phase equilibria studies of the $\mathrm{Pb}-\mathrm{SiO} 2$ system. $J \mathrm{Am}$ Ceram Soc. 2018;101:458-471

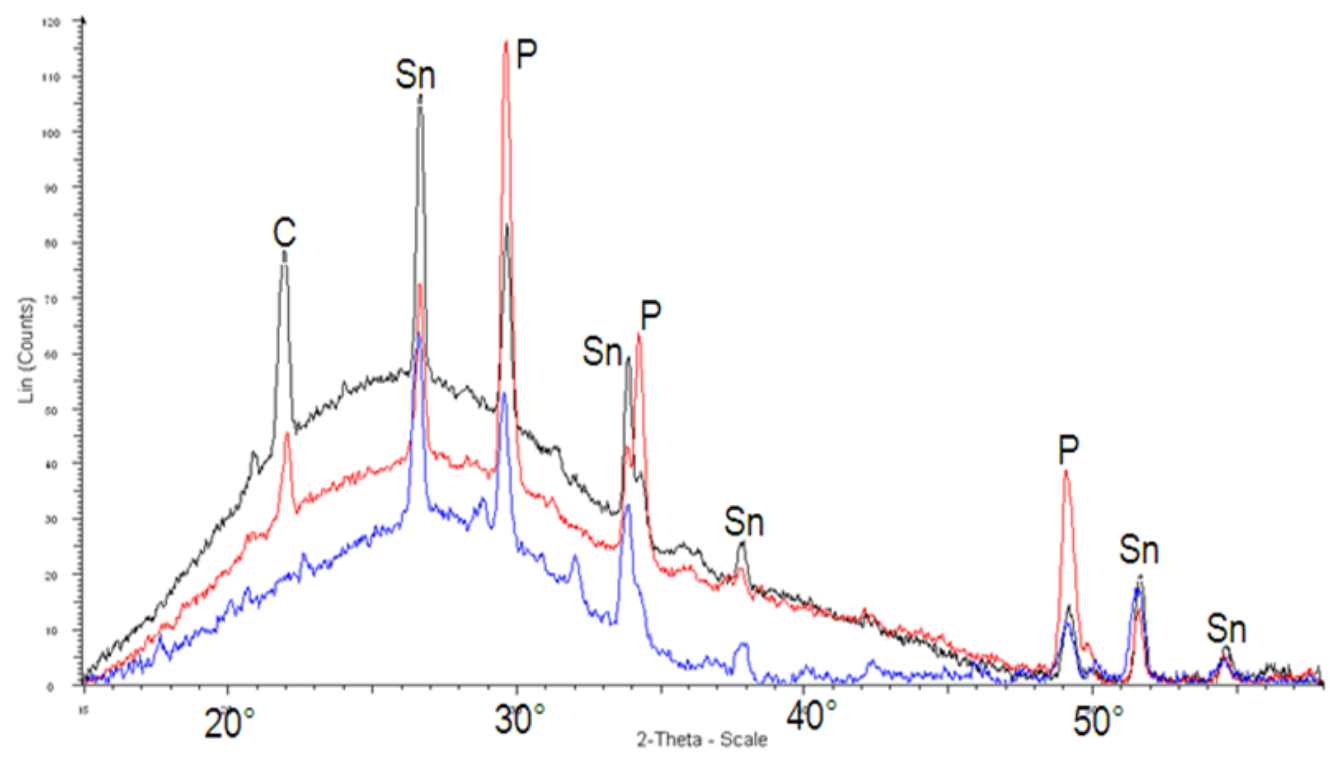

fig S4 : XRD diagrams for three glazes in the small room; glaze colors from bottom to top are respectively dark green, yellow and orange. The XRD peaks $\mathrm{C}$ stands for cristobalite, Sn for cassiterite and $\mathrm{P}$ for $\mathrm{Pb}_{2} \mathrm{SnSbO}_{6.5}$. Amorphous phase creates the "bump" between $2 \theta=20^{\circ}$ and $35^{\circ}$. 


\section{Detailed XRF results for the Altarpiece by Pisano}

Chemical concentrations in $\%$ oxide mass

Table S2: White glazes

\begin{tabular}{|l|l|l|l|l|l|l|l|l|l|l|l|}
\hline & $\mathbf{7 0}$ & $\mathbf{7 7}$ & $\mathbf{7 9}$ & $\mathbf{8 9}$ & $\mathbf{9 2}$ & $\mathbf{9 4}$ & $\mathbf{9 9}$ & $\mathbf{1 0 7}$ & $\mathbf{1 1 1}$ & $\mathbf{1 1 4}$ & $\mathbf{1 1 7}$ \\
\hline SiO2 & 55,21 & 59,50 & 35,56 & 49,95 & 65,76 & 57,07 & 57,41 & 42,47 & 34,46 & 42,91 & 52,26 \\
\hline K2O & 4,47 & 4,09 & 3,29 & 4,46 & 5,62 & 4,14 & 4,27 & 3,34 & 4,00 & 3,62 & 3,97 \\
\hline CaO & 2,59 & 3,00 & 2,32 & 2,65 & 3,19 & 2,71 & 2,63 & 3,34 & 6,65 & 2,16 & 2,53 \\
\hline TiO2 & 0,08 & 0,06 & 0,05 & 0,07 & 0,08 & 0,06 & 0,06 & 0,05 & 0,05 & 0,11 & 0,13 \\
\hline MnO & 0,02 & 0,02 & 0,01 & 0,02 & 0,02 & 0,02 & 0,02 & 0,01 & 0,01 & 0,02 & 0,02 \\
\hline Fe2O3 & 0,55 & 0,45 & 0,33 & 0,55 & 0,64 & 0,48 & 0,43 & 0,42 & 0,48 & 0,46 & 0,52 \\
\hline CoO & 0,02 & 0,02 & 0,01 & 0,02 & 0,02 & 0,02 & 0,02 & 0,02 & 0,01 & 0,01 & 0,02 \\
\hline NiO & 0,02 & 0,02 & 0,01 & 0,02 & 0,03 & 0,02 & 0,02 & 0,02 & 0,02 & 0,02 & 0,01 \\
\hline CuO & 0,14 & 0,21 & 0,19 & 0,57 & 0,18 & 0,21 & 0,12 & 0,13 & 0,44 & 0,34 & 0,27 \\
\hline ZnO & 0,08 & 0,03 & 0,04 & 0,03 & 0,04 & 0,04 & 0,03 & 0,02 & 0,02 & 0,03 & 0,03 \\
\hline SnO2 (K) & 6,32 & 7,22 & 5,50 & 7,27 & 8,00 & 8,10 & 8,25 & 5,25 & 5,56 & 6,36 & 7,49 \\
\hline SnO2 (L) & 0,73 & 1,39 & 1,80 & 0,85 & 0,95 & 1,37 & 1,62 & 0,97 & 1,43 & 1,52 & 1,69 \\
\hline PbO (L) & 32,26 & 32,19 & 25,80 & 34,96 & 37,43 & 39,62 & 41,77 & 30,25 & 26,76 & 29,81 & 31,30 \\
\hline PbO (M) & 25,18 & 24,94 & 19,38 & 27,05 & 31,42 & 38,15 & 40,11 & 25,50 & 17,29 & 27,36 & 27,52 \\
\hline
\end{tabular}

Table S3: Yellow - orange - brown glazes

67-75 Annunciation

78-97 Visitation

106-108 Left pillar 116 Coat

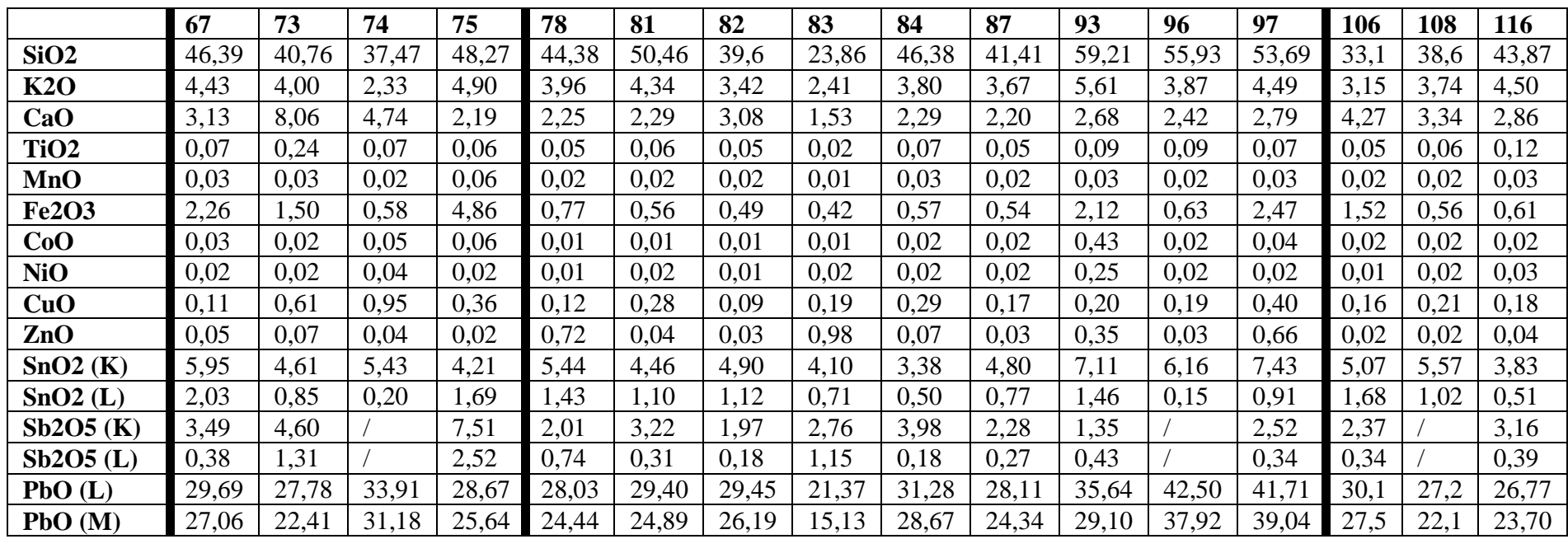


Table S4 : Blue glazes : 68-76 Annunciation 85-95 Visitation 105 left pillar in the Altarpiece

\begin{tabular}{|l|l|l|l|l|l|l|l|}
\hline & $\mathbf{6 8}$ & $\mathbf{7 2}$ & $\mathbf{7 6}$ & $\mathbf{8 5}$ & $\mathbf{9 0}$ & $\mathbf{9 5}$ & $\mathbf{1 0 5}$ \\
\hline SiO2 & 41,28 & 53,71 & 54,15 & 43,93 & 53,44 & 57,37 & 34,63 \\
\hline K2O & 3,20 & 4,93 & 4,32 & 4,27 & 4,61 & 5,06 & 5,47 \\
\hline CaO & 3,14 & 2,83 & 2,69 & 2,56 & 3,07 & 2,99 & 16,88 \\
\hline TiO2 & 0,07 & 0,09 & 0,06 & 0,07 & 0,08 & 0,08 & 0,13 \\
\hline MnO & 0,03 & 0,05 & 0,02 & 0,03 & 0,03 & 0,04 & 0,03 \\
\hline Fe2O3 & 2,33 & 3,65 & 1,15 & 1,72 & 1,12 & 2,90 & 5,03 \\
\hline CoO & 1,15 & 1,70 & 0,26 & 1,05 & 0,18 & 1,23 & 1,52 \\
\hline NiO & 0,45 & 0,57 & 0,14 & 0,54 & 0,12 & 0,62 & 0,73 \\
\hline CuO & 0,80 & 0,70 & 0,40 & 0,52 & 0,24 & 0,19 & 0,58 \\
\hline ZnO & 0,03 & 0,06 & 0,03 & 0,02 & 0,03 & 0,03 & 0,03 \\
\hline SnO2 (K) & 4,03 & 4,84 & 7,16 & 4,38 & 6,88 & 7,19 & 7,47 \\
\hline SnO2 (L) & 0,14 & 0,38 & 1,73 & 0,35 & 1,45 & 1,81 & 3,31 \\
\hline PbO (L) & 30,80 & 27,52 & 30,96 & 28,86 & 38,18 & 37,03 & 33,33 \\
\hline PbO (M) & 29,45 & 22,30 & 25,81 & 25,51 & 30,35 & 35,41 & 22,88 \\
\hline
\end{tabular}

Table S5 : $\quad 66$ green -69 to 110 turquoise glazes in the Altarpiece

\begin{tabular}{|l|l|l|l|l|l|l|l|}
\hline & $\mathbf{6 9}$ & $\mathbf{8 0}$ & $\mathbf{8 6}$ & $\mathbf{1 0 1}$ & $\mathbf{1 0 9}$ & $\mathbf{1 1 0}$ & $\mathbf{6 6}$ \\
\hline SiO2 & 42,53 & 48,39 & 54,73 & 52,94 & 45,80 & 33,39 & 40,71 \\
\hline K2O & 3,47 & 4,16 & 4,55 & 4,52 & 4,61 & 3,97 & 3,81 \\
\hline CaO & 2,91 & 2,41 & 2,39 & 3,90 & 3,75 & 8,05 & 2,58 \\
\hline TiO2 & 0,06 & 0,05 & 0,07 & 0,06 & 0,05 & 0,06 & 0,05 \\
\hline MnO & 0,02 & 0,01 & 0,02 & 0,02 & 0,02 & 0,02 & 0,03 \\
\hline Fe2O3 & 0,58 & 0,43 & 0,43 & 0,46 & 0,47 & 0,47 & 0,61 \\
\hline CoO & 0,03 & 0,02 & 0,01 & 0,02 & 0,02 & 0,02 & 0,03 \\
\hline NiO & 0,03 & 0,02 & 0,02 & 0,03 & 0,03 & 0,02 & 0,02 \\
\hline CuO & 4,02 & 0,86 & 0,58 & 3,53 & 3,6 & 1,25 & 2,23 \\
\hline ZnO & 0,04 & 0,14 & 0,03 & 0,04 & 0,04 & 0,04 & 0,04 \\
\hline SnO2 (K) & 5,38 & 5,87 & 5,44 & 8,27 & 6,27 & 5,57 & 5,75 \\
\hline SnO2 (L) & 0,68 & 1,33 & 1,07 & 2,50 & 2,18 & 1,65 & 1,67 \\
\hline PbO (L) & 30,18 & 29,10 & 29,00 & 38,32 & 28,58 & 29,24 & 30,08 \\
\hline PbO (M) & 28,95 & 25,67 & 23,69 & 35,23 & 24,40 & 22,30 & 28,68 \\
\hline
\end{tabular}

Table S6: $71-98$ Purple ; 91 red glazes in the Altarpiece

\begin{tabular}{|l|c|c|c|c|}
\hline & $\mathbf{7 1}$ & $\mathbf{8 8}$ & $\mathbf{9 8}$ & $\mathbf{9 1}$ \\
\hline SiO2 & 37,53 & 57,62 & 63,50 & 46,51 \\
\hline K2O & 1,91 & 4,87 & 5,22 & 4,44 \\
\hline CaO & 1,56 & 2,57 & 3,38 & 3,23 \\
\hline iiO2 & 0,06 & 0,09 & 0,08 & 0,07 \\
\hline MnO & 1,09 & 1,34 & 0,47 & 0,03 \\
\hline Fe2O3 & 0,42 & 0,69 & 0,57 & 2,26 \\
\hline CoO & 0,02 & 0,03 & 0,02 & 0,03 \\
\hline NiO & 0,02 & 0,03 & 0,02 & 0,02 \\
\hline CuO & 0,14 & 0,13 & 0,12 & 0,11 \\
\hline ZnO & 0,03 & 0,02 & 0,03 & 0,05 \\
\hline SnO2 (K) & 5,59 & 7,90 & 8,35 & 5,91 \\
\hline SnO2 (L) & 0,58 & 1,88 & 2,02 & 2,27 \\
\hline
\end{tabular}

30 


\begin{tabular}{|l|l|l|l|l|}
\hline PbO (L) & 35,38 & 37,39 & 39,84 & 29,69 \\
\hline PbO (M) & 35,91 & 33,14 & 35,12 & 27,08 \\
\hline
\end{tabular}

\section{Comparison Pd-XRF - XRF/XRD in the Cenador de Carlos Quinto}

The two XRF systems have been compared on standard glasses and on an ancient yellow glaze also analyzed by PIXE. ${ }^{23}$ Here, Pd-XRF and XRF-XRD have been used in different zones, Pd-XRF having been used mostly for tiles covering the exterior of the building. The concentration values (Table S7) from the two XRF systems are consistent. Compositions are similar except for Sn. It must be noted that XRF was not performed on the same points with the two systems. Pd-XRF was used once for the three glazes with Sn (table S7); two to four measurements were performed with XRF-XRD. The discrepancies appear mostly for Sn-L values; they can be explained by various factors: chemistry variations from point to point due to irregular glaze surface compositions from fabrication or from weathering (outside vs inside tiles); instrumental differences, XRF-XRD measuring for Sn-L layer thicknesses six times smaller than Pd-XRF. Concentrations in the $6.5-11 \mathrm{wt} \%$ range (Sn-K) are likely and give the white color due to opaque glazes.

Table S7: Cenador de Carlos Quinto. XRF average values of element concentrations (\% oxide mass) are given in relation to the Pd-XRF (a) or XRF-XRD system (b).

\begin{tabular}{|c|c|c|c|c|c|c|c|c|}
\hline \multirow[t]{2}{*}{ Colors } & \multicolumn{2}{|c|}{ White } & \multicolumn{2}{|c|}{ Blue } & \multicolumn{2}{|c|}{ Green } & \multicolumn{2}{|c|}{ Beige } \\
\hline & (a: $1 p t)$ & (b) & (a: $1 p t)$ & (b) & $(\mathrm{a}: 3 \mathrm{pt})$ & (b) & (a) & (b) \\
\hline $\mathrm{SiO2}$ & 44 & & 24 & & 27 & & 19 & \\
\hline K2O & 3 & 3.5 & 1.1 & 2.4 & 1 & 1.5 & 0.7 & 1.8 \\
\hline $\mathrm{CaO}$ & 2 & 5 & 1.5 & 4.1 & 2.45 & 4.1 & 1.2 & 4.4 \\
\hline $\mathrm{TiO}_{2}$ & 0.1 & 0.15 & 0.1 & 0.16 & 0.12 & 0.18 & 0.1 & 0.14 \\
\hline MnO & 0.02 & 0.03 & 0.02 & 0.02 & 0.03 & 0.05 & 0.02 & 0.03 \\
\hline $\mathrm{Fe}_{2} \mathrm{O}_{3}$ & 0.65 & 1.1 & 0.6 & 1 & 0.65 & 0.9 & 2.7 & 3.3 \\
\hline $\mathrm{CoO}$ & 0.01 & 0.01 & 0.23 & 0.43 & 0.01 & 0.01 & 0.03 & 0.01 \\
\hline NiO & 0.02 & & 0.12 & & 0.02 & & 0.01 & \\
\hline $\mathrm{CuO}$ & 0.09 & & 0.09 & & 2.2 & & 0.08 & \\
\hline $\mathrm{ZnO}$ & 0.03 & 0.02 & 0.02 & 0.01 & 0.03 & 0.01 & 0.04 & 0.04 \\
\hline $\mathrm{SnO}_{2}(\mathrm{~K})$ & 11 & 6.4 & 3.7 & 5.2 & 0.1 & 0.6 & 0.06 & 0.4 \\
\hline $\mathrm{SnO}_{2}(\mathrm{~L})$ & 5.5 & 21 & 1.1 & 9.6 & 0.06 & 1.25 & 0.25 & 0.7 \\
\hline PbO (L) & 34 & 32 & 28 & 30 & 33 & 30 & 33 & 29 \\
\hline PbO (M) & 29 & 51 & 22 & 32 & 33 & 41 & 33 & 36 \\
\hline $\mathrm{As}_{2} \mathrm{O}_{3}\left(\mathrm{~K}_{\beta}\right)$ & & & & 0.5 & & & & \\
\hline $\mathrm{Bi}_{2} \mathrm{O}_{3}(\mathrm{~L})$ & & & 0.6 & & & & & \\
\hline
\end{tabular}




\section{Optical microscopy and scanning electron microscopy examination of cross-sections}

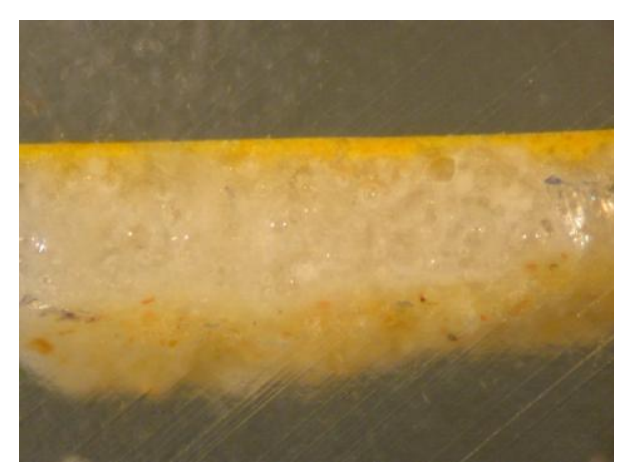

Fig. S5: cross-section optical microscopy image of a yellow glaze from the Palcio Gotico large room : $10 \mu \mathrm{m}$ yellow layer and 160-190 $\mu \mathrm{m}$ white layer on the body
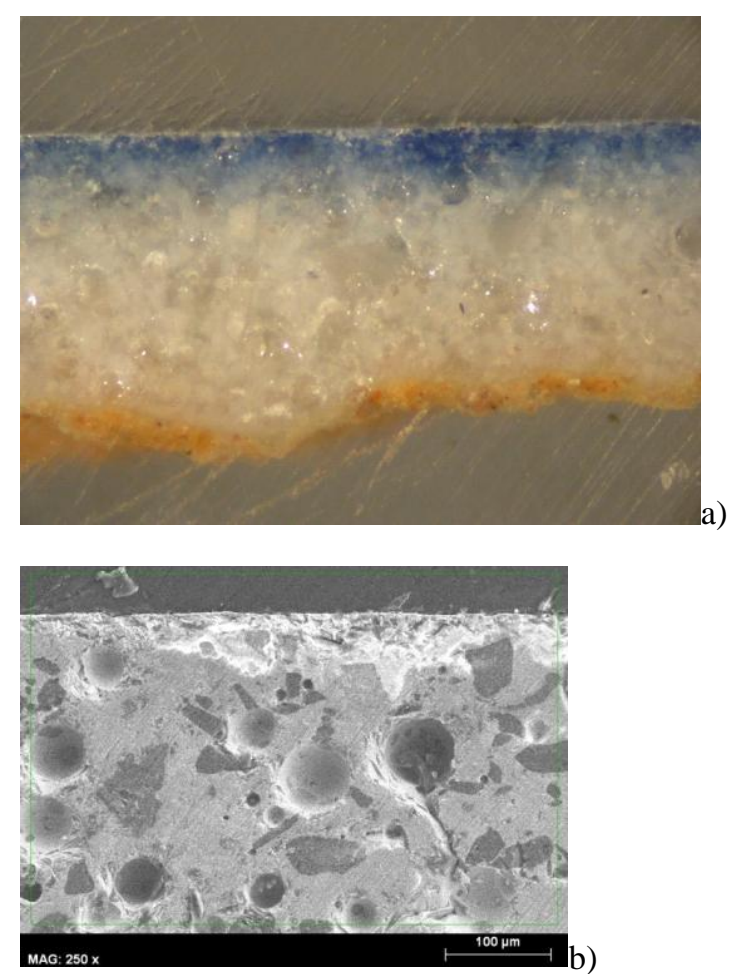
Fig. S6: double layer blue glaze from the Palacio Gotico large room (15-30 $\mu \mathrm{m}$ blue on 135-190 $\mu \mathrm{m}$ white):

a) optical microscopy;

b) SEM micrograph (secondary electron) showing large quartz and feldspar grains

a)

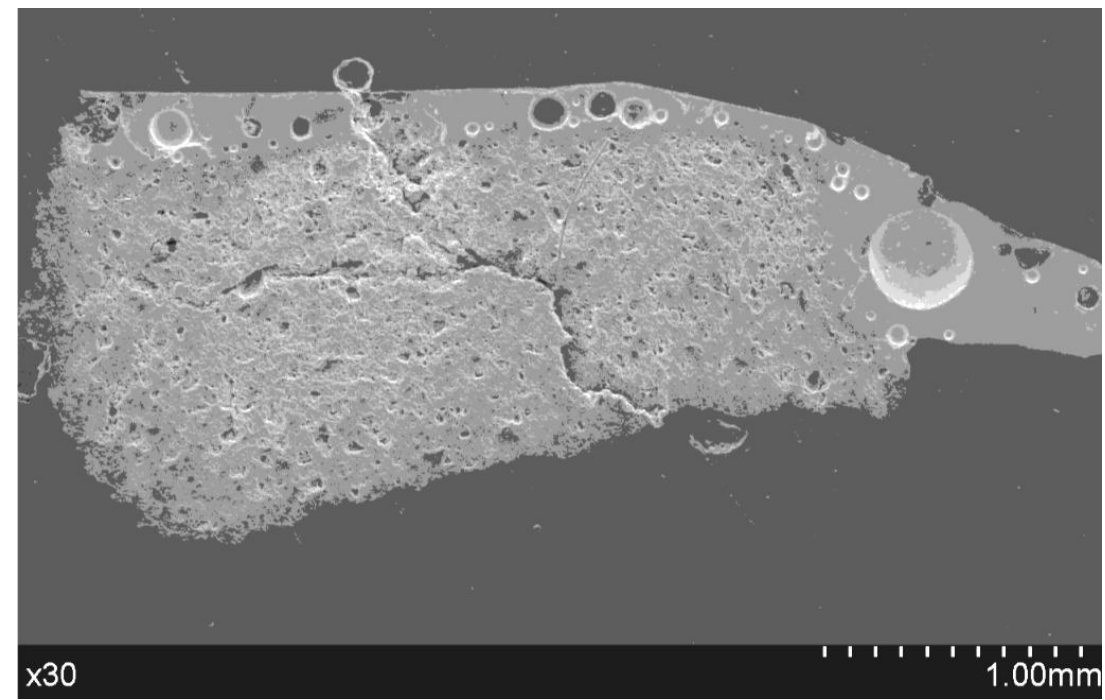




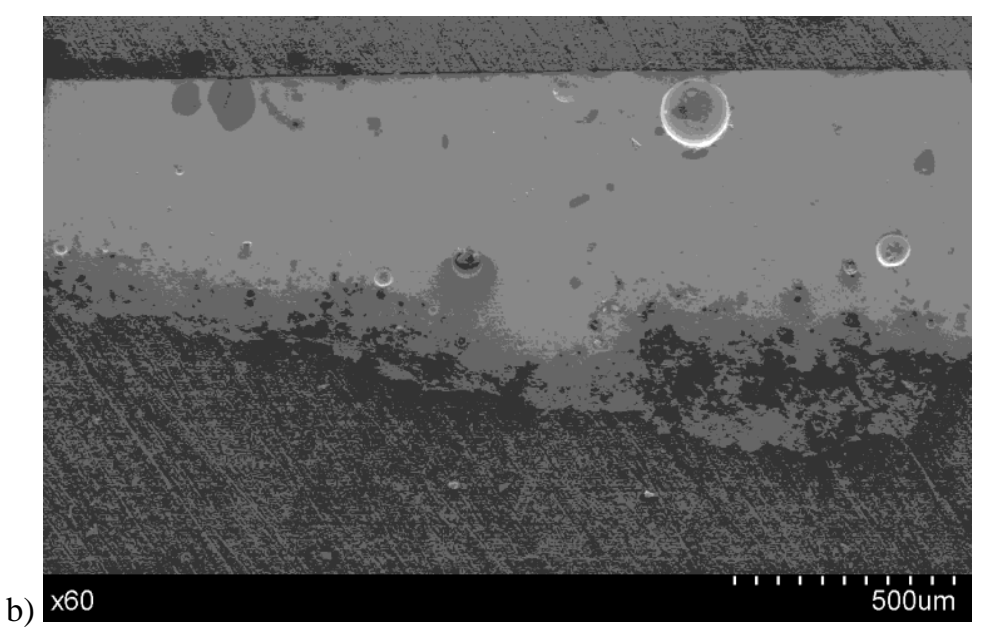

Fig. S7: SEM micrograph (secondary electron) of cross-sections from the Cenador de Carlos Quinto.

a) blue glaze, about $200 \mu \mathrm{m}$ thick on most of its length, above the body. The glaze includes about 20 bubbles, 5 of them being large and one being huge on the right.

b) large reaction zone (about $100 \mu \mathrm{m}$ thick) at the interface between the green glaze and the body 